\title{
De strijd om nieuwe maatschappijvormen
}

\author{
Citation for published version (APA):
}

Albeda, W. (1995). De strijd om nieuwe maatschappijvormen. Centrum voor Arbeidsverhoudingen Overheidspersoneel. https://doi.org/10.26481/spe.19950915wa

Document status and date:

Published: 15/09/1995

DOI:

10.26481/spe.19950915wa

Document Version:

Publisher's PDF, also known as Version of record

\section{Please check the document version of this publication:}

- A submitted manuscript is the version of the article upon submission and before peer-review. There can be important differences between the submitted version and the official published version of record.

People interested in the research are advised to contact the author for the final version of the publication, or visit the DOI to the publisher's website.

- The final author version and the galley proof are versions of the publication after peer review.

- The final published version features the final layout of the paper including the volume, issue and page numbers.

Link to publication

\footnotetext{
General rights rights.

- You may freely distribute the URL identifying the publication in the public portal. please follow below link for the End User Agreement:

www.umlib.nl/taverne-license

Take down policy

If you believe that this document breaches copyright please contact us at:

repository@maastrichtuniversity.nl

providing details and we will investigate your claim.
}

Copyright and moral rights for the publications made accessible in the public portal are retained by the authors and/or other copyright owners and it is a condition of accessing publications that users recognise and abide by the legal requirements associated with these

- Users may download and print one copy of any publication from the public portal for the purpose of private study or research.

- You may not further distribute the material or use it for any profit-making activity or commercial gain

If the publication is distributed under the terms of Article $25 \mathrm{fa}$ of the Dutch Copyright Act, indicated by the "Taverne" license above, 
De redicticcommissic

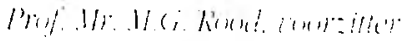

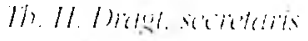 \\ 11/. Ahritio

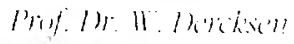

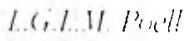 \\ $1 / 1 /$ hisisiog

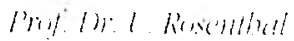

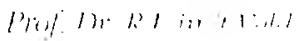 \\ 11.1 \\ $\therefore 1$
}

llet centrum roor drbeidsverhoudingen Overheidspersoncel rervult in her overteg tussen orerheidswerkgevers en centables van overheidspersoned eren intiërende en ondersteunende functic. Datrnaast zijn in het centrum ondergebracht het secretariaat van

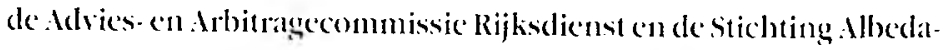
lecrstocl. De lecestoel is verbonden atn de Inasmusuniversiteit Rotterdam voor het vakgebied arbeidsroorwatekenvorming bij de overheid.

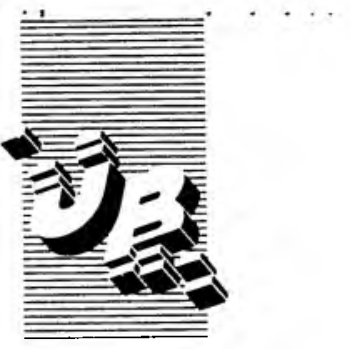

De uitleentermijn verstrijkt op:
Universiteltsblbliotheok

Rijksuniversiteit Limburg

Postbus 616

6200 MD Maastrıchı
Gelieve deze publicatie tijdig te retourneren of (telefonisch) verlenging van de vitleentermijn aan te vragen. lling vitn de collectiere ganisatics in die sector ananderingsproces.

latform roor discussic, ullen de adviezen van de in geamotecrde vorm in ook gevralagde en ongebeleid en veranderingen : sector voor uitgave in roden ingediend bij het 


\section{De strijd om nieuwe maatschappijvormen}

De strijd blijft, op elk niveau

15 september 1995

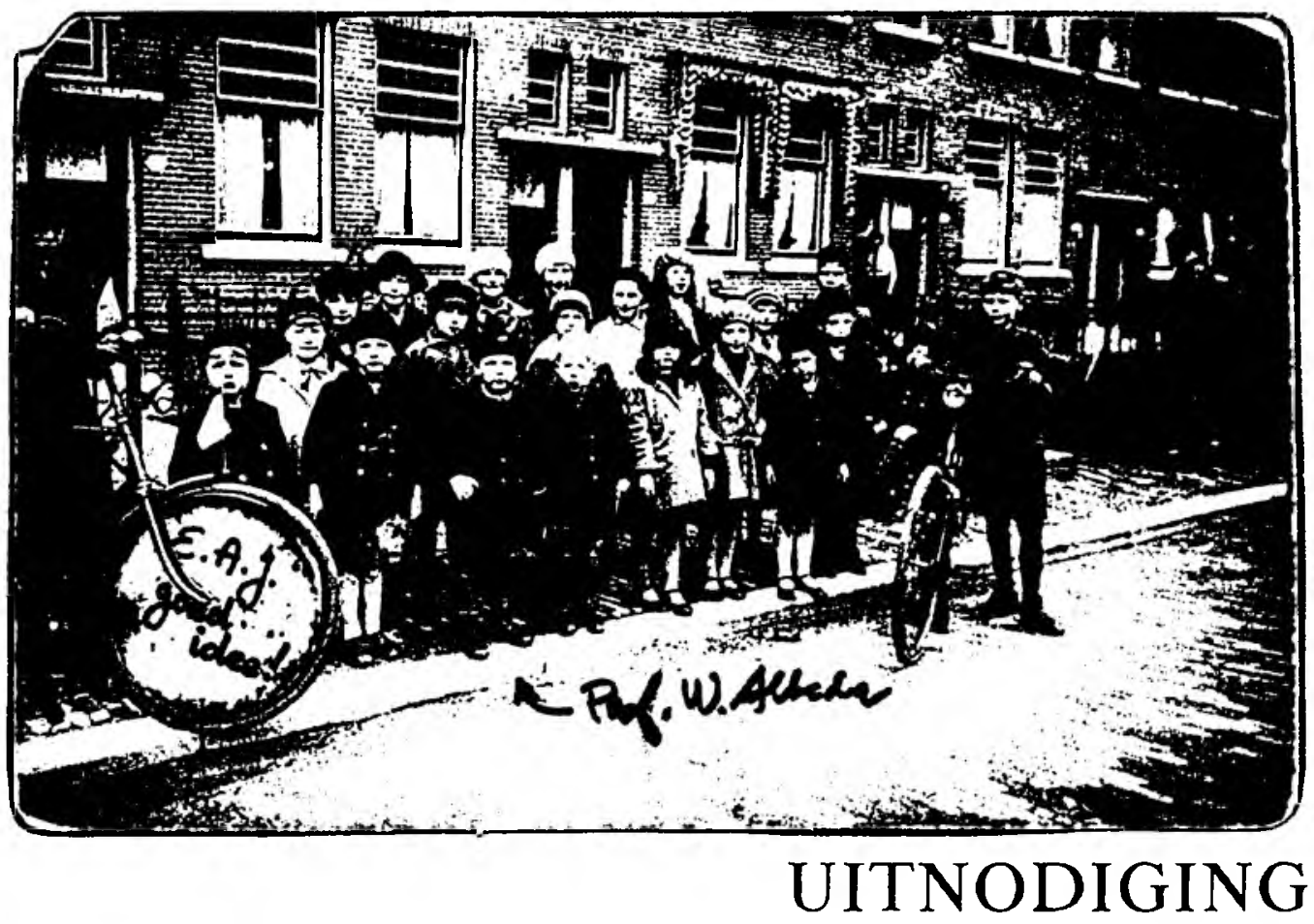




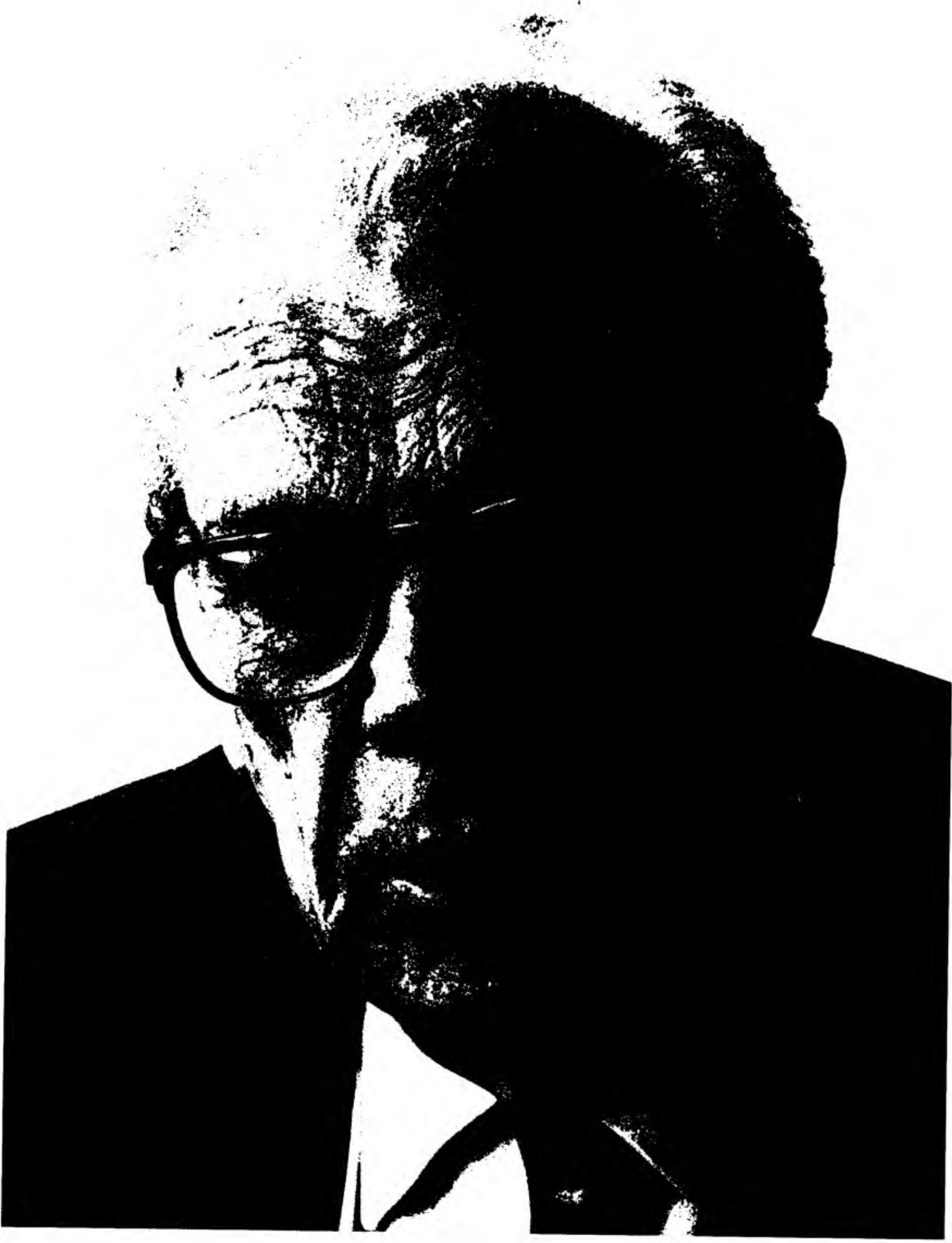




\section{ME \\ De strijd \\ VAB \\ 950 \\ om nieuwe \\ maatschappijvormen}

\section{De strijd blijft, op elk niveau}

Afscheidsrede prof. dr. W. Albeda

Rijksuniversiteit Limburg

15 september 1995

Prof. dr. W. Albeda 
$P=141892153$

\section{Universiteitsbibliolhock}

Aljksuniversiteit Limburo

Druk: Kerckelosch bv. Zeist

NUGi 693

ISBN 905.1090820

- 1995. Centrum voor Arbeidsverhoudingen Overheidspersoncel, s-Gravenhage

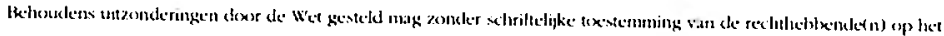

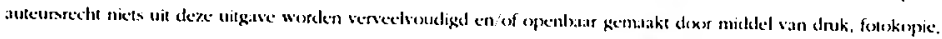

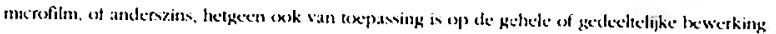

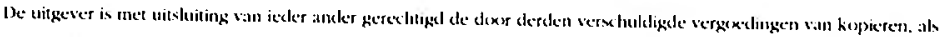

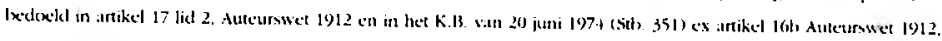
te innen en of diatrexe in en butess reche op te treden

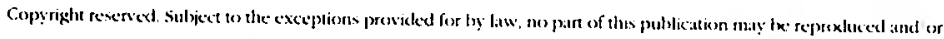

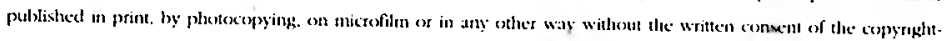
holder(s): the same applies os whole or partiat adaptitions.

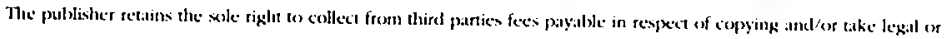
other action for this purpose. 


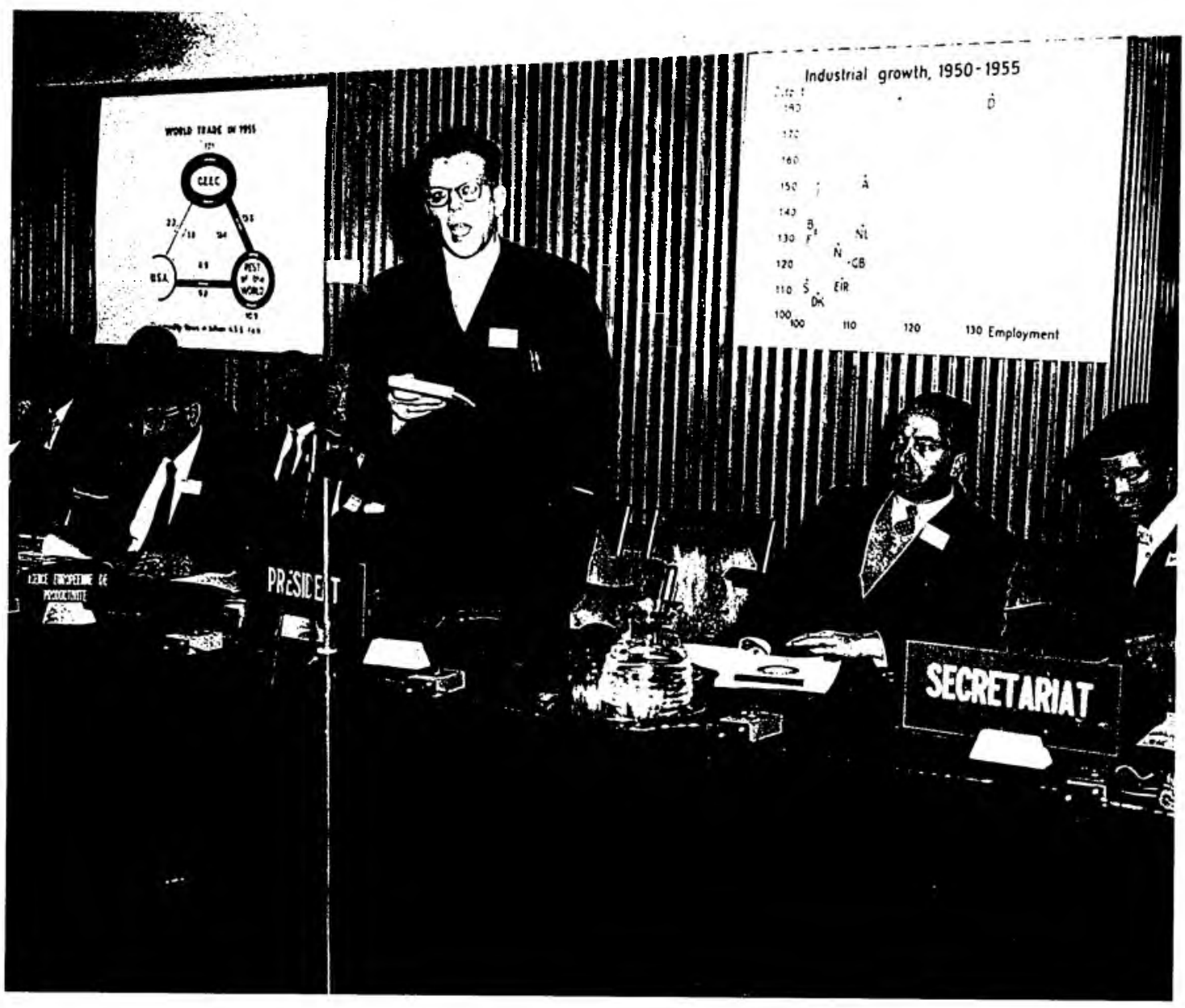




\section{De strijd om nieuwe maatschappijvormen*}

\section{De strijd blijft, op elk niveau}

In 1922 schreef P.S. Gerbrandy zijn "De strijd voor nieuwe maatschappijvormen"1. Toen ik nadacht over een onderwerp voor dit afscheidscollege moest ik denken aan de titel van dit boek, dat in zo sterke mate mijn gedachtenwereld heeft bepaald. Ik las er mijn proefschrift nog eens op na. Kernpunt was toen voor mij de vraag op welke wijze een meer rechtvaardige maatschappijvorm kon worden gerealiseerd. Ik schreef over de rol van de vakbeweging, omdat ik in het voetspoor van Gerbrandy in de vakvereniging een belangrijk instrument zag om het kapitalisme niet zozeer af te schaffen, als wel te organiseren. Gerbrandy wees de weg van de collectieve arbeidsovereenkomst als instrument voor het realiseren van verhoudingen, waarin werkgevers en werknemers samen op den duur bouwen aan een "regerende macht". Onderhandelingen zouden als eindpunt een gezamenlijk bewind kunnen hebben.

Op het eerste gezicht lijkt deze sympathieke redenering, waarbij de $\mathrm{CAO}$ als ad hoc regeling uiteindelijk uitmond in gezamenlijk bestuur, te zijn uitgelopen op een cloodlopende weg.

De PBO, die een gedachtengang als die van Gerbrandy trachtte te realiseren was, om een understatement te gebruiken, geen succes. Zij ging trouwens niet de weg die Gerbrandy zag. Pieter Sjoerd bestreed deze bedrijfsorganisatie-van-bovenaf, die niet paste in zijn gedachte van de geleidelijke, door bedrijfsgenoten zelf bestuurde, groei. Hij zag die wetgeving als opgelegd, als "in strijd met den eerbied voor het wordende en voor het leven". Een opvatting, die achteraf bevestigd is.

De werkelijke ontwikkeling was niet die van een bedrijfsorganisatie met bevoegdheden uitmondend in gezamenlijke bewindvoering. Alleen de SER, het toporgaan van de PBO, bleek een levensvatbare constructie, als formele instantie van onze overlegeconomie, zoals die

* Ik dank de heer Th.H. Dragt voor zijn opmerkingen naar aanleiding van een eerdere versie van dit betoog.

' P.S. Gerbrandy, De strijd voor nieuwe maatschappijvormen, Amsterdam, z.j. (1928). 
ooit functioneerde in de geleide loompolitiek en een rol speelt in de blijvende vormen van inspraak van de sociale partners in het socialeconomisch beleid.

Achteraf bezien had Gerbrandy een visie op het begrip bedrijfstak, die pré-industrieel was. Doordat hij zijn voorbeeld nam in het functioneren van organisaties in de toen nog ambachtelijke grafische industrie kon hij nog filosoferen over de bedriffstak als een gemeenschap. De technologische ontwikkeling makte een einde aan zulke bedrijfstakken. Landbouw, ambacht en bouwnijverheid behieklen lang de structuur waarin bedrijfsorganisatie zin had. Maar elders triomfeerde de markt. In de discussie met Dooyeweerd², clie de gehele gedachte van de bedrijtstak als gemeenschap als onhistorisch verwierp, had Dooyeweerd het bij het rechte eind. Ik noteerde datt reeds in mijn Rotterdamse scriptie van $1950^{3}$ (wat mij later op een op een vermaning van Marinus Ruppert kwam te staan).

- Herman Dooyeweerd 1894-1977. Breedte en actualiteit van zijn filosofie, onder redactie van H.G. Geersema en anderen. Kok Kampen 199i.

"Zie overigens H.\&.S. Woldring. Dooyeweerd contra Gerbrandy en Ruppert (in derelfde bundel).

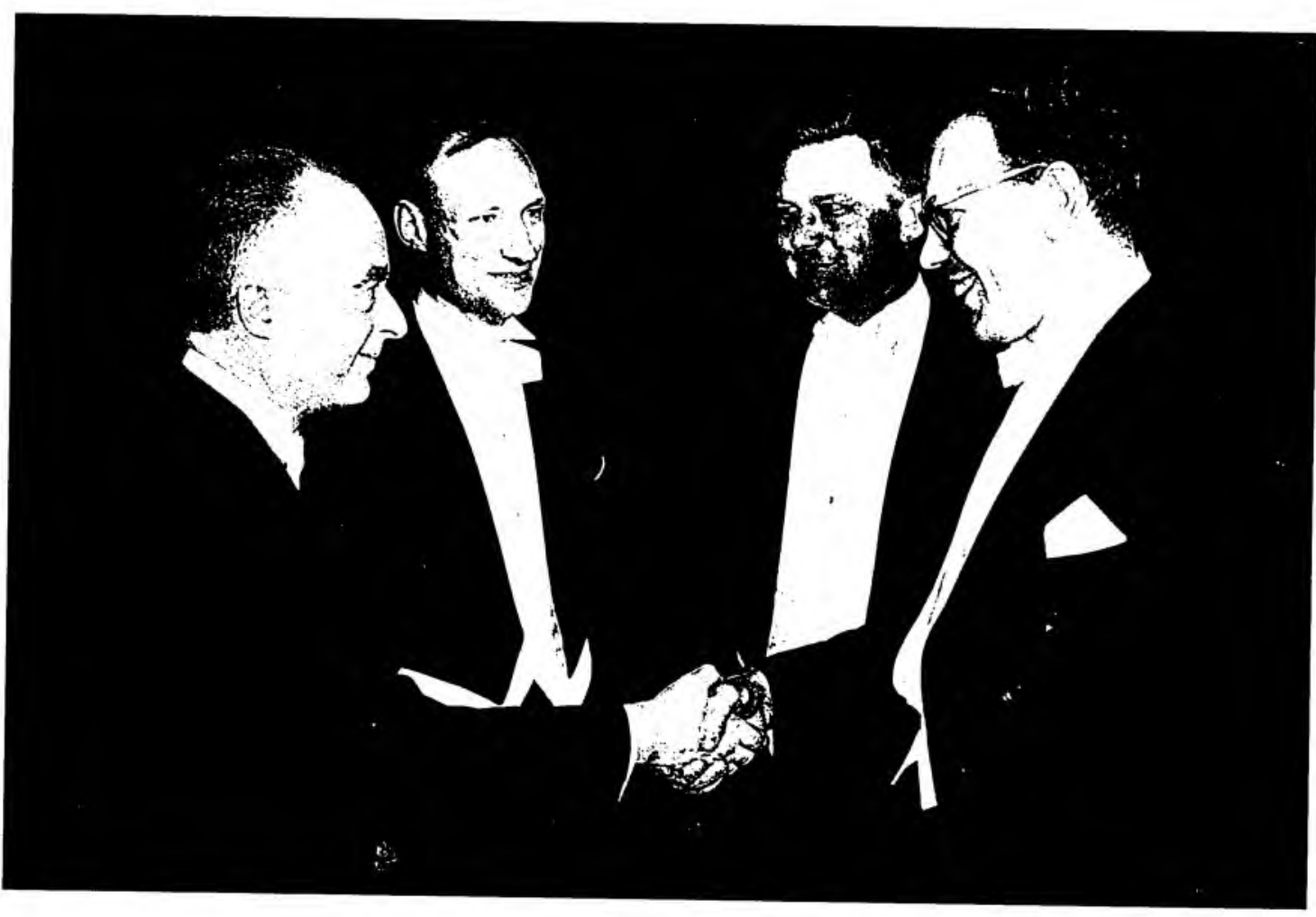




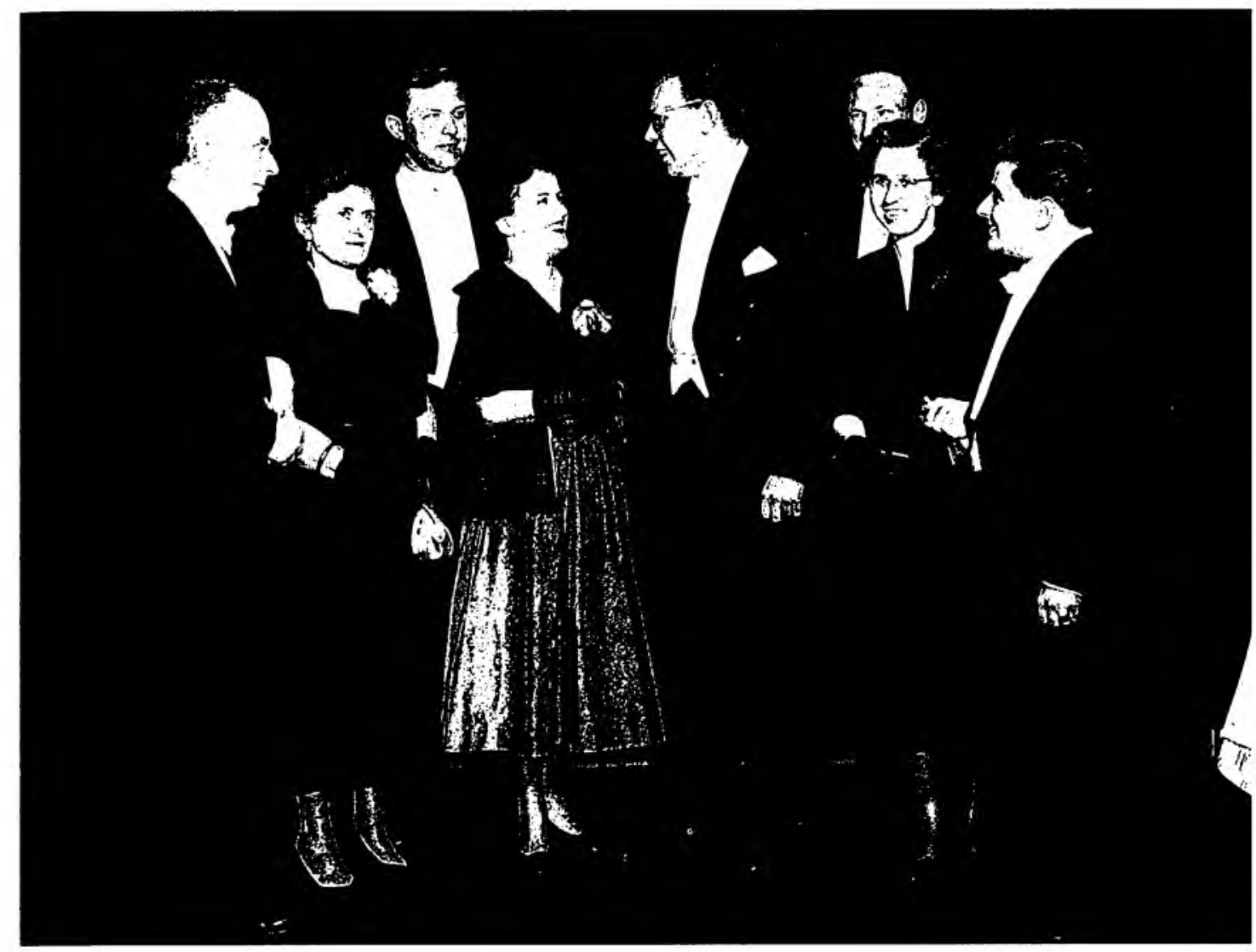

Met paranimfen, ecblgenote en promotor in 1957.

Als het er op aankomt, kan men stellen, leidde de door Gerbrandy aangeprezen weg van de ongestuurde, door bedrijfsgenoten zelf geleidelijk, tastenderwijs gevonden, vormen tot een heel andere ontwikkeling dan hij hoopte en voorzag. Alles wat blijft van zijn gedachtengang is zijn methodiek. Niet de constructie van nieuwe maatschappijvormen van bovenaf maar de groei van onderop.

Nee, wie vandaag de strijd voor nieuwe maatschappijvormen aan wil gaan, kan niet echt voortborduren op Gerbrandy. In wezen zijn wij veeleer bezig met het opruimen van de resten van de maatschappijvormen, zoals Gerbrandy ze dacht. Het streven naar verregaande decentralisatie, deregulering en flexibilisering, de roep om matwerk, het nieuwe geloof in de markt lijken een einde te maken aan vormen van bedrijfsorganisatie. Ook aan georganiseerd kapitalisme? 
In zijn Capitalisme contre Capitalisme voerde Michel Albert' het pleidooi voor het "Rijnlandse model". Kenmerken van dit model zijn:

1. Het gatat om relatief egalitaire samenlevingen. Salarisschalen zijn minder open dan die van de Angelsaksische landen.

2. Het algemeen belang heeft er voorrang boven het strikt individuele belang. De gemeenschap walarin het individu leeft en werkt is belangrijk: de onderneming, de stad, de organisatie, de vakbond zijn even \%ovele beschermende en stabiliserende structuren.

3. Deze watadering voor collectiviteiten sluit de vrije markt niet uit, maar zorgt voor een kader watrin de markt kan functioneren.

4. De sociale markteconomie vind $z$ 'n weerspiegeling in het politieke bestel. Er zijn banden tussen de maatschappelijke organisaties en politieke partijen of parlementariërs.

+ Michel Albert. Cappitalisne contre capilalisme, Seuil, Patrijs 1991.

\section{Rollerdamse oratie}

oktober 1966.

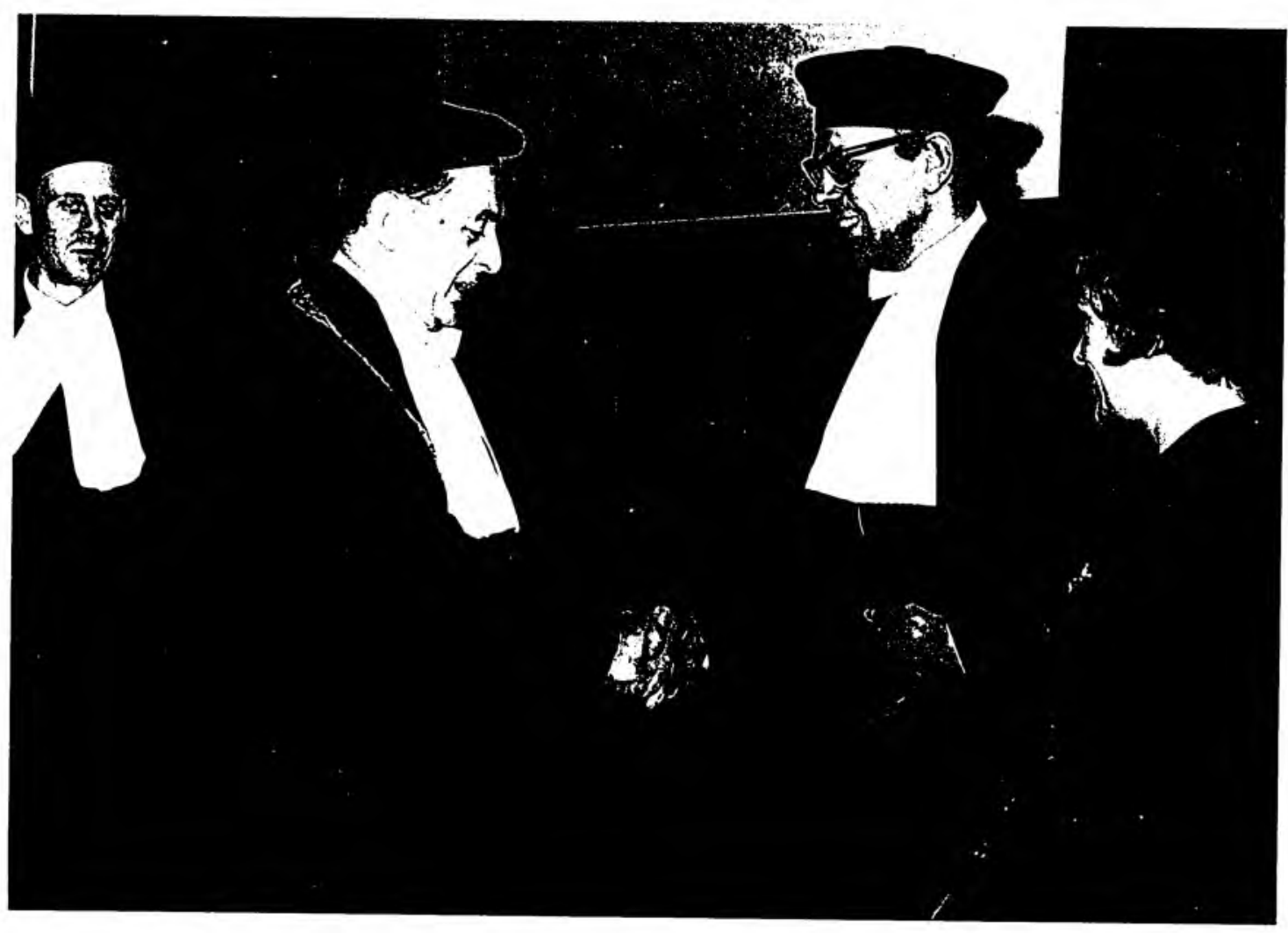


Het gaat om een markteconomie, walarvan de werking begrensd wordt door de eisen, gesteld door rechtvaardigheid en duurzaamheid.

Men kan zeggen dat Gerbrandy's strijd voor nieuwe maatschappijvormen, hoezeer ook passend in de tijd waarin hij schreef, nu niet meer actucel is. Maar betekent dit dat die strijd over is, en niet meer relevant? Naar mijn opvatting, en dat is ook de belangrijkste these van dit betoog, is deze strijd meer actueel dan ooit. Misschien moet ik dit nuanceren: deze strijd is altijd actueel, zolang zoiets als een verzorgingsstaat bestaat. Een verzorgingsstaat is immers een symbiose tussen een markteconomie en een socialal actieve staat. De markteconomie kenmerkt zich door permanente verandering aangestuurd door technische vernieuwing, en dus is de verzorgingsstaat altijcl weer in crisis's. Telkens zijn weer veranderingen nodig. Het arrangement, dat uitstekend functioneren kon in de jaren zestig, bleek in de jaren zeventig en tachtig in problemen te komen. De strijd om nieuwe maatschappelijke vormen hoort bij de verzorgingsstaat.

Maar wat zijn de stellingen, waarom het gaat in deze strijd? Wanneer we dit proberen te formuleren, dan blijkt dat Gerbrandy's grote tegenstander, het individualistisch kapitalisme meer levend is dan ooit te voren. De discussie gaat nog steeds over (om met Albert te spreken) georganiseerd of ongeorganiseerd kapitalisme.

In hoeverre laat het kapitalisme zich organiseren? Michel Albert is daar optimistisch over. In zijn visie zijn vormen van communautair of collectief kapitalisme meer efficiënt en dus brengen zij meer welvalart clan vormen van ongeorganiseerd kapitalisme. Hij wijst dan met name op Duitsland en de andere Noordwest Europese landen.

Het lijkt goed om nader te preciseren, waarover we het eigenlijk hebben. Kapitalisme veronderstelt vrij functionerende markten. Georganiseerd kapitalisme lijkt daarom een contradictie in te houden. Maar in de praktijk blijkt dit anders te liggen. Juist de overgang van een staatseconomie in de landen van Oost Europa naar een markt economie liet scherp zien, hoezeer een markteconomie blijvend een regelende overheid en regelende instituten en organisaties nodig heeft om te kunnen functioneren. Elke vorm van kapitalisme, die wij kennen,

${ }^{5}$ W. Albeda, De crisis hoor bij de verzorgingsstaat, Kok, Kampen 1992. 


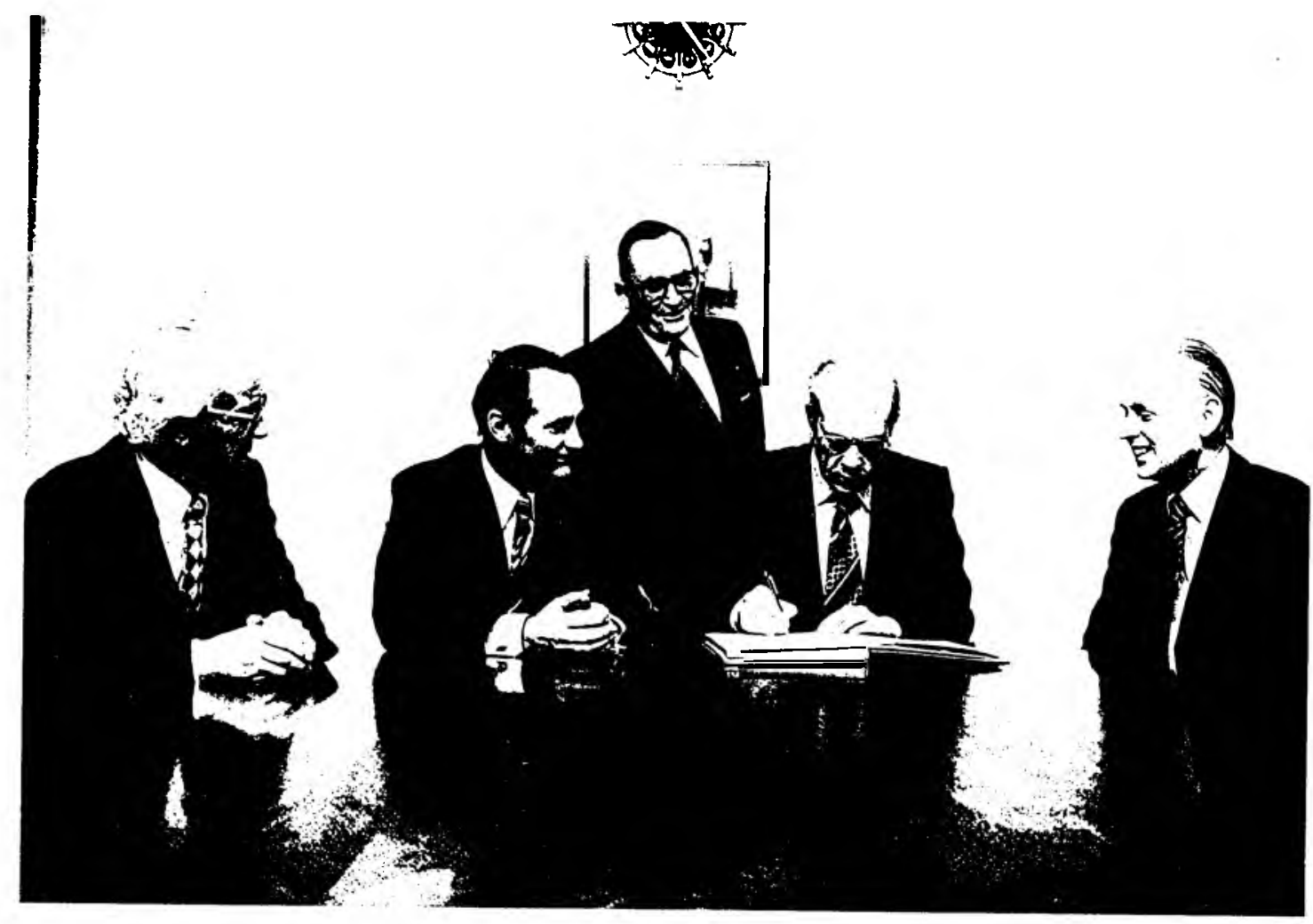

Overdrachi ministerschap Boersma aan dbr: Albeda 19 december 1977.

heeft z'n eigen vorm van organisatie. David Soskice' wees erop, dat zich twee grote families van kapitalisme laten onderscheiden. De Angelsaksische familie laat weinig coördinatie zien tussen bedrijven en banken en tussen bedrijven onderling, bovendien wordt de overheid er weinig beinvloed door het bedrijfsleven. Daar tegenover stelt hij een Noord-West Europees/Japanse familie van kapitalisme, gekarakteriseerd door veel intensievere coördinatie tussen bedrijven en banken en bedrijven onderling en met name banden tussen overheid en bedrijfsleven.

Mijn veld van onderzoek van deze middag is minder breed, dan clat van Soskice. Ik wil mij beperken tot de organisatie van wat men de sociale kant van de markteconomie zou kunnen noemen, dus met name de arbeidsverhoudingen en de arbeidsmarktrelaties. Ook daar is er een cluidelijke scheiding tussen enerzijds de Angelsaksische wereld,

${ }^{6}$ Zie CEPR Bulletin, Londen, nr. 52 augustus 1992.9 
en anderzijcls West Europa. Zowel Amerikanen als Engelsen kijken met enige verbazing naar de vormen van samenwerking tussen, wat men in continentaal Europa, maar zeker niet overzee, sociale partner's noemt.

Nederland had lange tijd een zcer geprononceerd stelsel van tripartite co-operatie. Ik sprak over de ontwikkeling van dit stelsel bij gelegenheden, die mijn universitaire carrière markeerden.

In mijn Rotterdamse Oratie van 1966 hield ik mij bezig met de problematiek van Centraal Sociaal Economisch Beleid. Op dat moment was het centrale beleid met betrekking tot de arbeidsverhouclingen en cle loonvorming over z'n hoogtepunt heen. De geleide loonpolitiek was sinds de loonexplosie ter ziele gegaan. Ik heb de situatie van de jaren zestig vaak zo beschreven, dat men kan zeggen dat Regering en Parlement eigenlijk heimwee hadden naar de geleide loonpolitiek. Het was zo duidelijk, dat het inpassen van de loonhoogte in de macro-econonische mogelijkheden gewvenst en zelfs noodzakelijk was. Hoe zou men anders volleclige werkgelegenheid kunnen handhaven en daarbij inflatie vermijden? Hadden cle jaren vijftig niet bewezen hoe groot de mogelijkheden waren, en bovendien bleek toen niet dat het ging om een goed en effectief instrument? Waarom zou men dat dan uit handen geven?

Maar zowel cle werkgevers als de vakverenigingen dachten daar anders over. Zij voelden zich in hoge mate gefrustreerd door de geleide loonpolitiek, die hun wezenlijke verantwoordelijkheid ontnam en grote spanningen bracht tussen leiding en achterban in hun organisaties. Het was voor hen een sfeer van: "dit nooit meer".

Ondertussen functioneerde de overlegeconomie redelijk door: Centrale onderhandelingen brachten elk jaar quasi contracten, die men gralg als rituele dansen kwalificeerde, al hadden ze wel een zekere werking. De SER adviseercle de regering stap voor stap en de arbeidsvrede bleef uniek.

Toen ik in 1990 mijn Utrechtse oratie hield, was de wereld wezenlijk veranderd. Na de looningrepen van de jaren zeventig kwamen de maatschappelijke organisaties in 1982 tot een akkoord. Aan die looningrepen leverde ik eind 70-er jaren tot verbazing van velen en tot 
op zekere hoogte ook van mijzelf een eigen bijdrage. Gelukkig blijkt niet alleen de toenmalige minister van Sociale Zaken gebukt te gatan onder de Wet van het Voortschrijdende Inzicht, doch is dat ook mijn overbuurman aan de overlegtafel, de toenmalige voorzitter van luet FNV, de heer W, Kok overkomen. Als ik toen had kunnen voorspellen welke inzichten mijn gesprekspartner nog eens vanuit een andere verantwoordelijkheid zou openbaren, dan zou dat overleg in de door mij immer beoogde harmonie zijn afgesloten. Dat het kan verkeren, geldt ook voor vakbondshestuurders die ministeriële verantwoorelelijkheid gatan dragen. zegt deze voormalige secretaris van het CNVen oudminister van Sociate Zaken.

Naast loonmatiging werd in het genoemde akkoord van ' 82 ook decentralisatie en arbeidstijdverkorting overeengekomen. Een nieuwe fase in onze arbeidsverhoudingen kwam daarmee naar voren, een fase gekenmerkt door een nieuwe adviserende rol van de Stichting van de Arbeid en de instelling van de Raad voor het Overheidspersoneelsbeleid als pendant in de publieke sector van SER en Stat: Decentralisatie, maar binnen een redelijk functionerende overlegeconomie.

$\mathrm{Nu}$ is het 1995. De decentralisatie heeft doorgezet en de overlegeconomie is meer dan ooit in discussie. Bij het jubileum van de Stichting van de Arbeid in clit voorjaar bleek dat deze institutie, die a.h.w. het boegbeeld vormt van onze overlegeconomie, niet langer onomstreden is ${ }^{7}$, al spraken zowel werkgevers als werknemers en cle Minister van Sociale Zaken- naar ik mag alannemen namens het Kabinet - zich expliciet uit voor de voortzetting ervan. Zij, die in hun columns in de opiniebladen en kranten de overlegeconomie al als een door de knieën zakkende olifant ten grave willen dragen,kunnen zich nog een keer verdiepen in de heldere analyse van minister Melkert. Kritisch, waar vraagtekens moeten worden geplalatst, duidelijk waar de waarde van. onverminderd betekenisvolle functies wordt aangeduid.

Kan men dan zeggen, dat de aan ons stelsel inherente centralisatie aan het verdwijnen is? Ik denk dat dat overdreven zou zijn. Welke mate van decentralisatie we ook kennen, de bedrijfstak CAO overheerst nog op de meeste terreinen zolang het individuele arbeidscontract en de

${ }^{7}$ Maarten van Bottenburg, Aan den Arbeid, uitgeverij Bert Bakker 1995. 


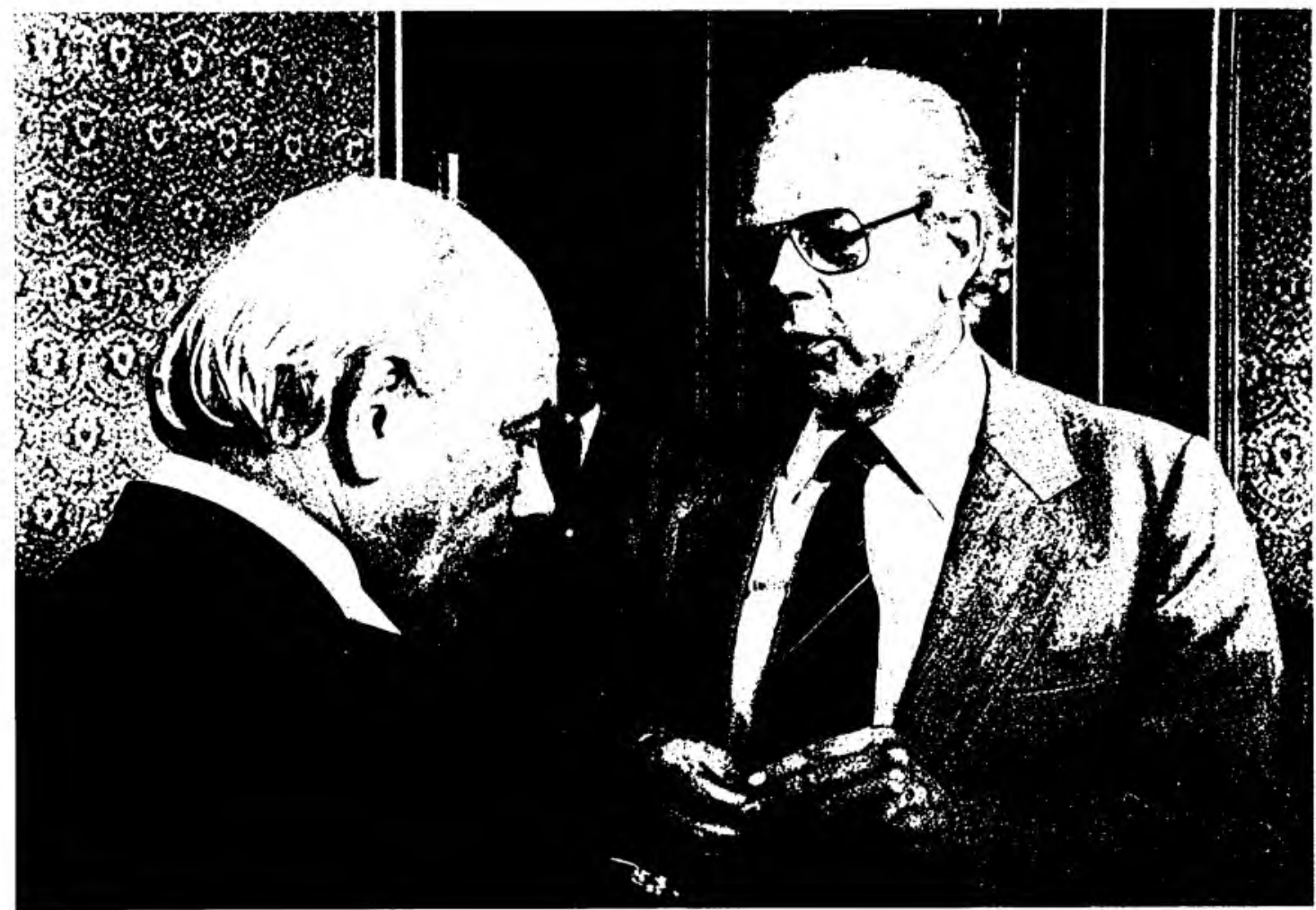

Overleg met J. M. den Uyl in 1977.

ondernemingscontracten het collectief contract niet hebben verdrongen. Het zou wat ver gaan om te spreken van het einde van nogal centralistische arbeidsverhoudingen. In veel gevallen gaat het eerder om een verdergaande "articulazione" om met de Italianen te spreken, een verdergaande detaillering van afspraken naar de ondernemingen toe.

Die verclergaande detaillering is noodzakelijk, omdat er nieuwe punten op de agenda staan, die slechts op het niveau van de onderneming (en soms zelfs van de werkplek) kunnen worden geregeld. Ik denk dan aan de vooral cloor de werkgevers gewenste flexibilisering en de vooral door de vakverenigingen verlangde arbeidstijdverkorting. Men $k a n$ in dit verband ook wijzen op de veel verdergaande diversifiëring van de arbeidsmarkt, door de groeiende dienstensector en de nieuwe technologieën, met een (om met De Closets te spreken) antiTayloristisch vooroordeel ${ }^{8}$.

\footnotetext{
${ }^{*}$ François de Closets, Tous ensemble, Seuil, Parijs 1985.
} 
Maar kan men spreken van het begin van het einde van de overlegeconomie, nu de verplichting voor de Regering on de SER om advies te vargen is vervallen? Ik denk, dat die conclusie te ver zou gaan. Men kan immers twee kanttekeningen maken bij dat besluit:

1. De regering kan uiteratard altijd, met name bij belangrijke besluiten het advies aan de SER en - voor specifiek op de overheidssectoren gerichte problematiek - alan de ROP valagen. De Kamer kan daarop aandringen. De in het begin van deze kabinetsperiode weer opduikende behoefte atan een primaat van de politiek kriigt weer de noodzakelijke politieke gestalte van het zoeken nalar een breed vlak van maatschappelijke acceptatie. De SER en de ROP vervullen daarbij als met name de SER niet als "politieke excuus-Truus" wordt misbruikt en hij zijn werkwijze actualiseert - een blijvende waardevolle functie.

werden bet eens.

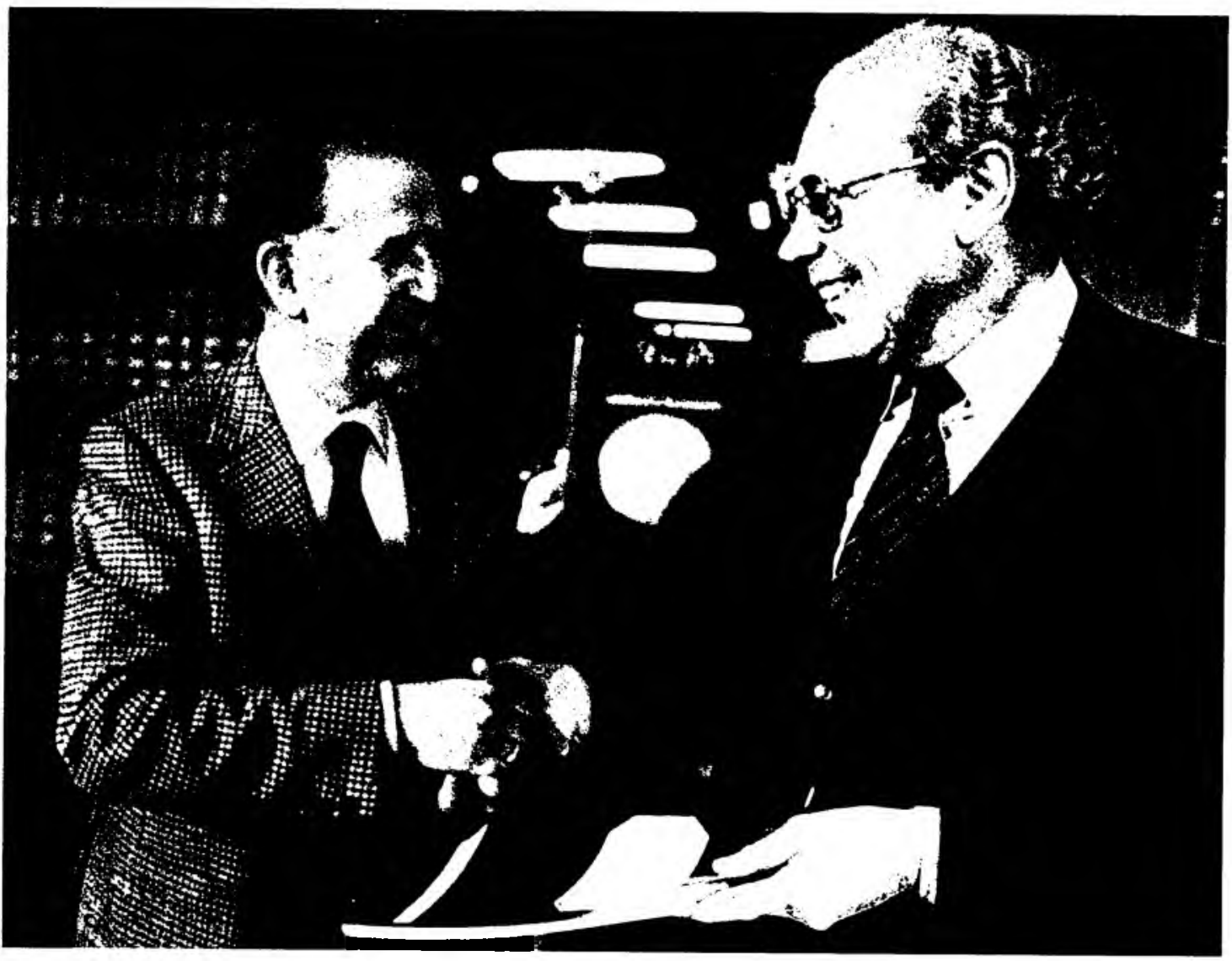


2. De algemene verplichting had ook z'n schaduwzijde. Het zogenaamcle koelkastkarakter van de SER heeft ongetwijfeld bezwaren. Daarbij komt, dat in veel gevallen van bijna automatische besluitvorming het advies vragen nodeloos tijdrovend is. Mijn liefde voor en geloof in de overlegeconomie nam niet weg, dat ik mij als Minister daaraan vaak heb geërgerd. Ook de wijze waarop de SER de adviesfunctie uitoefent kan best een onderwerp van overleg en bijstelling zijn.

Onze arbeidsverhoudingen worden van twee kanten onder druk gezet. Aan de ene kant is er de decentralisering die vooral technologisch is bepaald, aan de andere kant de schijnbaar daaraan tegengestelde ontwikkeling van de Europeanisering- en zelfs globalisering - van onze economie.

De Europeanisering van de economie heeft niet geleid tot een ontwikkeling in de richting van een groei naar Europese arbeidsverhoudingen. Maar zij leidt er wel toe dat voor de bedrijfstakken die voor de Europese- of de wereldmarkt werken, geldt, dat wat er in dezelfde bedriffstakken in de andere landen gebeurt, voor hun onderhandelingspositie belangrijker is dan wat er in andere bedrijfstakken in Nederland gebeurt. Men kan dus stellen, dat zowel de decentralisatie als cle Europeanisering het centrale niveau van de arbeidsverhoudingen aantast. Ik zie dan ook geen concrete centrale loonafspraken in de komencle jaren.

Wél is het interessant om vast te stellen, dat de groei naar een Europese overlegeconomie enigszins in het zichtveld komt, gegeven Delors' initiatieven voor de "sociale dialoog" en de plannen van Santer. In wezen gaat het claarbij om een ontwikkeling in cle richting van de Franse arbeidsverhoudingen. Indien de Commissie maatregelen op sociaaleconomisch terrein overweegt,dient zij eerst de Europese organisaties van werkgevers en werknemers om advies te vragen. Indien deze organisaties de betrokken maatregelen zelf willen ontwikkelen, moet de Commissie zich onthouden van acties op dat terrein. Het is jammer, dat het Sociaal-Economisch Comité niet een rol is toebedeeld in de "sociale dialoog". Maar een ontwikkeling naar overlegeconomie is onmiskenbaar. Het gaat hier echter wél om een overlegeconomie "van bovenaf", terwijl in nationale staten een omgekeerde ontwikkeling, van beneden naar boven, plaatsvond. Ik acht het overigens een goede ont- 


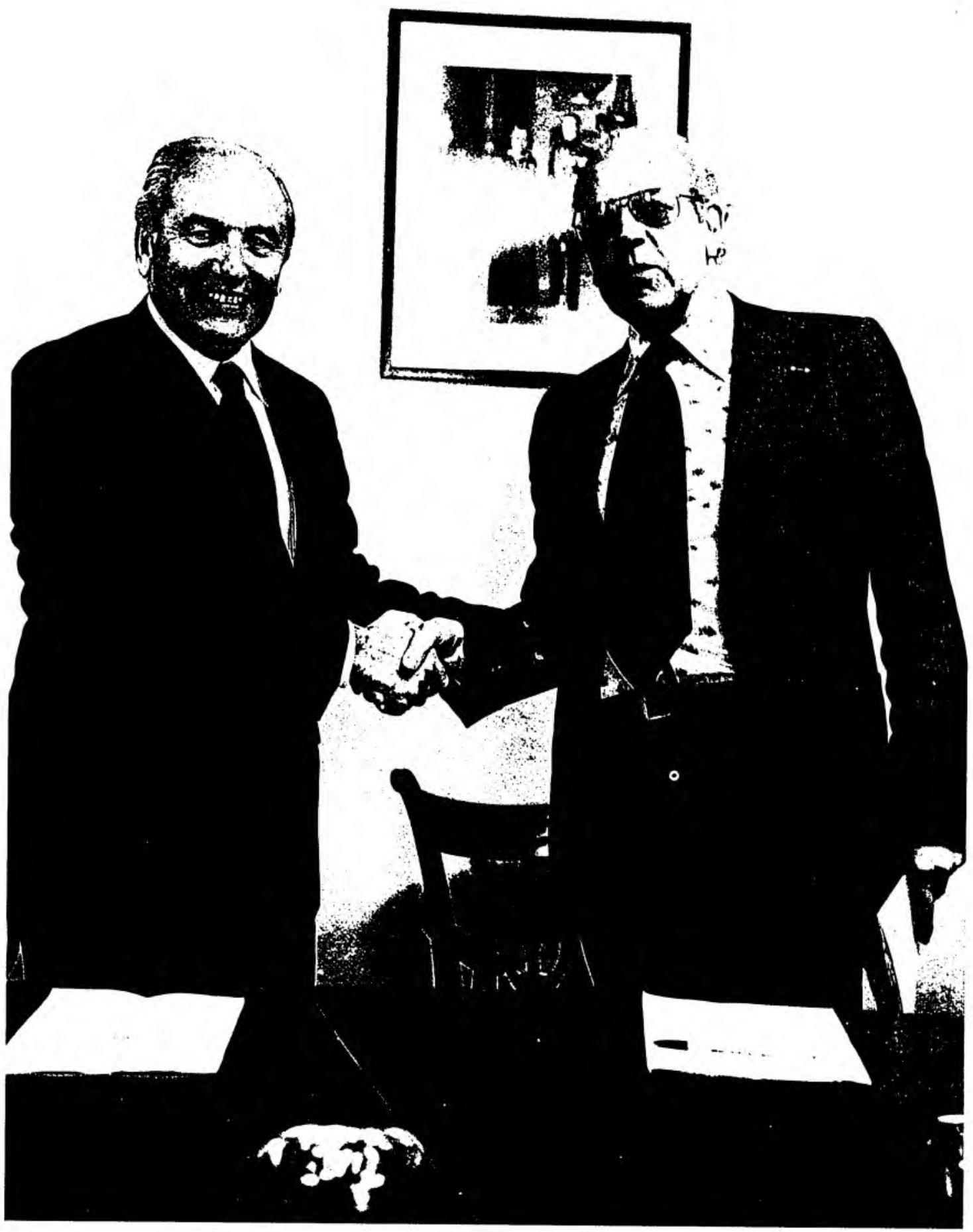

Ontmoeting met Blanchard (ILO), Den Haag 1980. 
wikkeling dat nu ook vanuit de vakbeweging de "sociale dialoog in Europa" steeds hoger op de agenda en in de onderzoeksprogramma's is geplaatst.

Het meest bedreigend voor de ontwikkeling van de collectieve arbeidsverhoudingen is de blijvend lagere organisatiegraad in een aantal bedrijfstakken (en met name ook in de nieuwere sectoren ), terwill in cle publieke sector de organisatiegraad hoog blijft.

Tegelijkertijd kan men vaststellen dat in de- wat de arbeidsvoorwaardenvorming betreft -veel beter georganiseerde publieke sector een nieuwe ontwikkeling plaatsvindt, waardoor de collectieve onderhandelingen meer impact en betekenis krijgen dan tevoren. Ik denk daarbij aan de onderhandelingen op basis van het overeenstemmingsvereiste, dat een proces naar meer gelijkwaardigheid tussen sociale partners inluidt, de conflictbeheersende en emanciperende rol die de Advies en Arbitragecommissie in de publieke sector kreeg én de groei naar het Centrum Arbeidsverhoudingen voor Overheidspersoneel, het CAOP. De sectoralisatie van de overheid, waarbij 8 bedriffstakken werden gevormd, heeft dit CAOP bij uitstek tot een intermediair én expertisecentrum in het totale proces van arbeidsvoorwaardenvorming en geschilbeslechting bij de overheid gemaakt. In deze overheidssectoren kan men spreken van een belangrijke vernieuwing in het systeem van collectieve onderhandelingen en van een versterkte overlegeconomie. De politiek heeft ontdekt, dat ze als verantwoordelijke voor de kwaliteit van de "Arbeidsorganisatie Overheid" ook aangesproken kan en moet worden op haar kwaliteit als werkgever. Mijn ervaringen vanuit de 11 jaar bestaande Advies- en Arbitragecommissie leert me dat - zeker in de vorige kabinetsperiode - de overheidswetgever heeft ontdekt dat sociale wetgeving ten opzichte van werkgevers en werknemers niet ophoudt bij de poort van de overheid. Ien Dales zei niet voor niets dat de overheidswerkgever alleen dan specifieke maatregelen moet entameren als de bijzondere positie van de overheidswerkgever dat dringend noodzakelijk maakt. Het proces van normalisatie in de arbeidsverhoudingen bij de overheid heeft zich - met een beroep op het primaat van de politiek - niet laten tegenhouden. Ook in Regeerakkoorden kan je het water van de Rijn niet van Rotterdam naar Bazel laten stromen en blijkt - ik verwijs naar het recente principeakkoord in de grote rijkssector - het nieuwe "sector- en onderhandelingsmodel" voor beide partijen boeiende kansen te bieden. In velerlei opzichten heeft het proces van arbeidsvoorwaardenvorming bij de 
overheid een zeer eigentijds en dynamisch karakter gekregen dat bij vele gelijkgestructureerde landen om ons heen - en ver datarbuiten oprechte bewondering wekt. Kennelijk blijkt er nog veel mogelijk in het spanningsveld tussen budgettaire randvoorwatrden van de overheidswetgever en de emanciperende verhouding lussen overheidswerkgevers en -vakbeweging

Mijn onlangs aan de Erasmus-universiteit benoende collega's Vonhoff en Wilke hebben ieder vanuit hun eigen invalshoek de komende jaren vanuit de leerstoel - waar ik zowel qua inhoud als naimgeving toch enige affiniteit mee mag hebben - een nog nauwelijks ontgonnen doch zeker breed veld van onderzoek en wetenschappelijke ontwikkeling voor zich liggen. Ik wens ze vanaf deze plats veel succes met de uitvoering van hun leeropdacht.

In weerwil van het feit, dat ook in de marktsector het proces van heroriëntatie van werkgevers en werknemersorganisatie tot nieuwe vormgeving van oorspronkelijke basisstructuren leidt en de rolverdeling een afgeleide is van zich ontwikkelende mattschappelijke verhoudingen, kan

mijn conclusie niet een andere zijn dan de vaststelling, dat er geen sprake is van een wezenlijke aantasting van het systeem van collectieve arbeidsverhoudingen en van de overlegeconomie. Mar moeten de arbeidsmarktregelingen niet wijken voor een betere arbeidsmartktwerking? Het is ook voor de niet zo geïnteresseerde buitenstalander cluidelijk, dat van vele zijden gepleit wordt voor een betere marktwerking, en dat men de huidige werkloosheid tenminste gedeeltelijk wijt aan de manier waarop de arbeidsmarkt georganiseerd is.

Om welke organisatievormen gaat het daarbij? Het lijkt mij, dat het eigenlijk meer gaat om (overheids)regelingen, dan om de eigen regelingen der maatschappelijke organisaties. Ik noem clan

1. De ontslagregeling.

2. De beperkingen die de CAO oplegt.

Maar weer, de kritiek richt zich vooral op de manier warop de overheid omgaat met de $\mathrm{CAO}$, namelijk de Algemeen Verbindend Verklaring van de $\mathrm{CAO}$.

3. De invloed van de sociale zekerheid.

4. Het minimumloon.

5. De regeling van tijdelijke arbeid. 


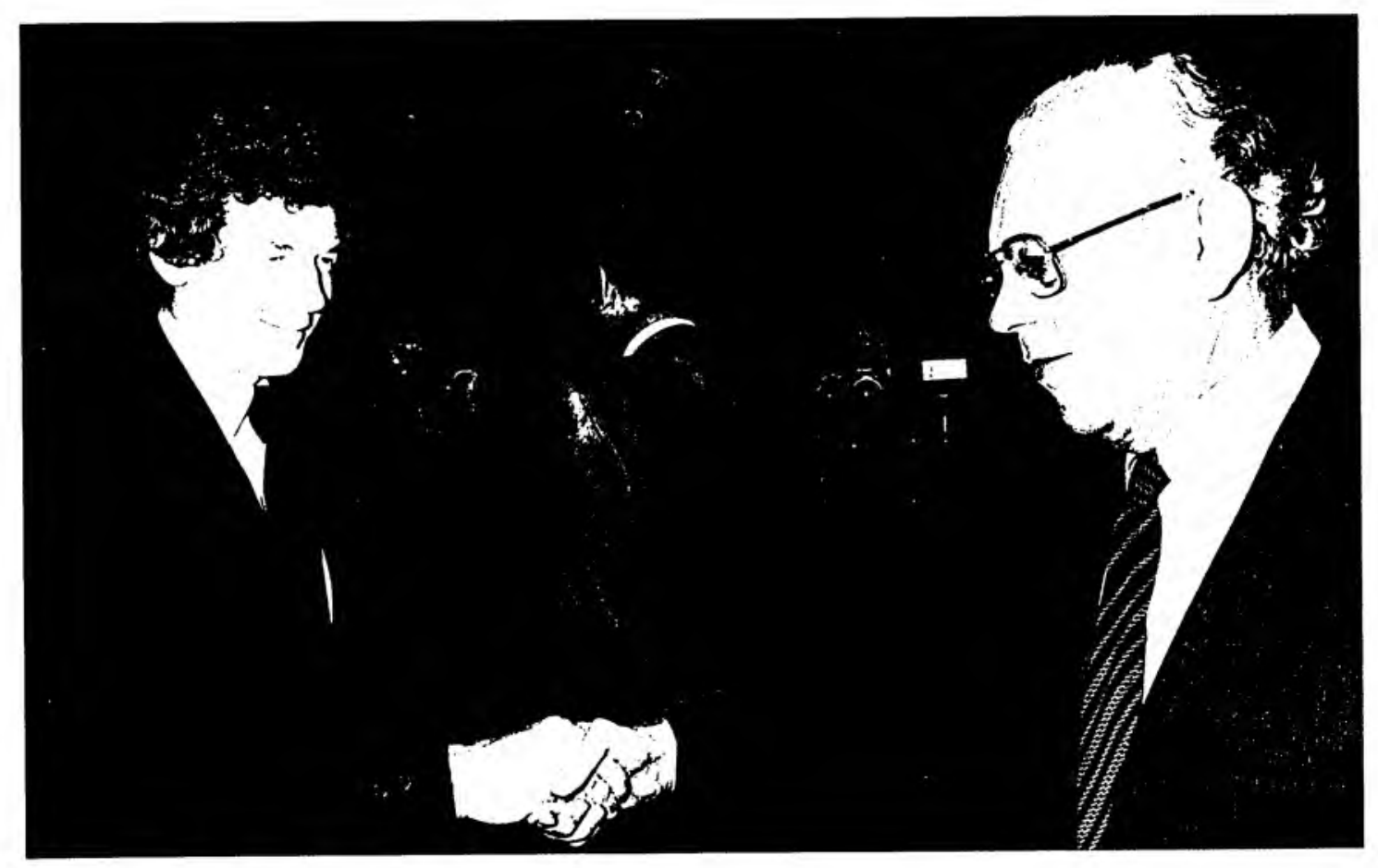

Ontmoeting met FNV-voorzilter de beer W. Kok.

Over elk van deze regelingen een enkele opmerking,

1. Reeds in het rapport van de Commissie-Wagner, waarvan ik lid was, komt de gedachte naar voren dat, al klinkt het wat paradoxaal, een liberalisering van het ontslagrecht de aarzelingen bij ondernemers om mensen in dienst te nemen zou kunnen wegnemen. Wie wel eens mensen heeft moeten ontslaan, weet hoe moeilijk en kostbaar dit kan zijn.

2. De Algemeen Verbindend Verklaring. Eigenlijk is de AVV een mooi instrument omdat het neerkomt op de erkenning van de zijde van de overheid dat bedrijfsgenoten recht kunnen scheppen. Ovenveging was daarbij mede, dat het alternatief voor de AVV gezien werd in praktijk van het verplichte lidmaatschap, ondersteund door de secundaire boycot (zie de Amerikaanse praktijk). De aandacht wordt er thans op gericht, dat het er vaak op neerkomt dat de Minister wettelijke kracht geeft aan afspraken, waarmee hij het wellicht helemaal niet eens is.

Men kan hier twee opmerkingen over maken.

Selectieve verbindendverklaring brengt de Minister op een gevaarlijk 
pad. Wanneer hij elke CAO bepaling wil beoordelen voor hij tot AVV overgat wordt de AVV tot een instrument voor gedetailleerd ingrijpen in het arbeidsvoorwardenoverleg.

Eigenlijk brengt dit mij ertoe te stellen clat de Minister moet kiezen tussen wèl of niet verbindend verklaren. Een "beetje" lijkt mij riskant.

Het is overigens nog niet eens zeker of het afschaffen van de Algemeen Verbindend Verklaring alleen matr schadelijk is voor de collectieve arbeidsverhoudingen. Men mag alannemen dat na een tijd van arbeidsonrust, omdat de vakverenigingen toch de naleving van de $\mathrm{CAO}$ willen afdwingen, een toestand ontstaat warbij de ongeorganiseerden meer aănleiding zullen vinden om zich te organiseren, omdat zij anders belangrijke voordelen zullen missen.

3. In wezen is het punt van de invloed van het functioneren van de sociale zekerheid op de arbeidsmarkt pas naar voren gekomen, toen de volledige werkgelegenheid niet langer gerealiseerd werd. Daarvoor kon men stellen: volledige verzorging makt volledige werkgelegenheid mogelijk, volledige werkgelegenheid makt volledige verzorging betaalbaar. Toen het eerste deel van deze vaststelling niet langer halalbaar bleek, verviel ook het tweede deel. We zoeken thans in wezen naar een vorm van sociale zekerheid die a) betaalbaar is, en die b) de eliminering van die werkloosheid niet in cle weg staat.

Punten, die daarbij van belang zijn, vormen de uit de sociale zekerheid voortvloeiende "wig" en de prikkel om weer aan het werk te gaan. Uitgangspunten voor een meer arbeidsmarkt conforme sociale zekerheid zijn, dunkt mij:

A. Minimaliseren van de druk op de loonkosten, met name aan de onderkant waar van huis uit de druk het grootst is. Te denken is daarbij aan premievrijstelling en afschaffing van BTW over arbeidsintensieve diensten.

B. Wellicht beperking van het "staatsstelsel" tot een garantie op het minimum niveau. Wie meer wil kan hetzij individueel, hetzij via zijn organisatie bij private verzekeringsinstellingen terecht.

\footnotetext{
${ }^{9}$ W. Albeda, De crisis van de werkgelegenheid en de verzorgingsstaat, inalyse en perspectief, Kok Kampen 1984.
} 


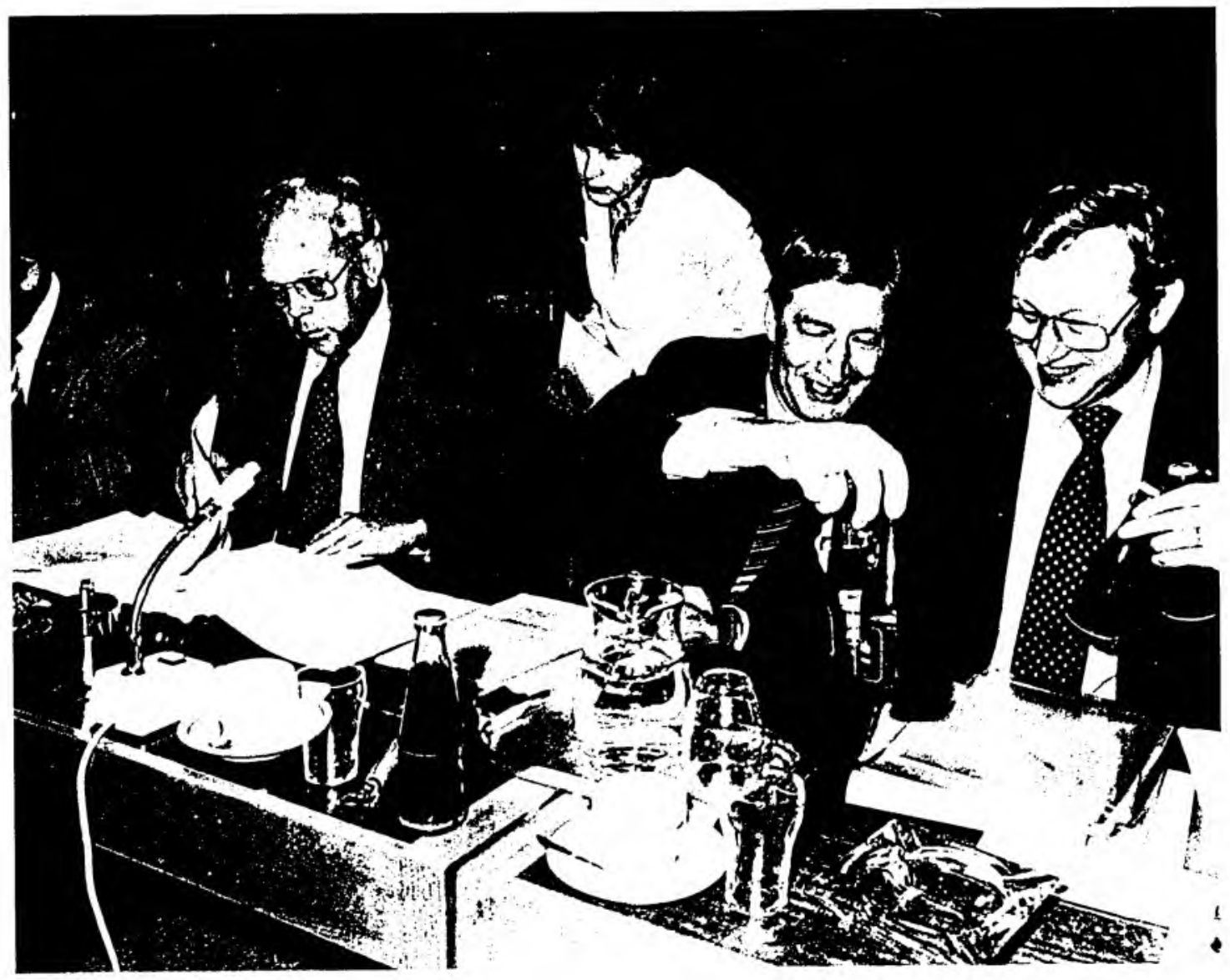

Het loonoverleg met de ministers

Andriessen en Van agl.

4. Het minimumloon. Betogen dat de hoogte van het minimum niet uitmaakt, lijken mij niet zo geloofwaardig. Dit impliceert nog niet verlaging of afschaffing ervan. Het Amerikaanse alternatief van de "working poor" lijkt niet aanvaardbaar. Andere wegen moeten worden bewandeld om weinig geschoolde arbeid betaalbaar te maken.

5. De tijd waarin men meende, dat tijdelijke arbeid zeer restrictief geregeld moest worden, ligt denk ik achter ons. Meer en meer zijn wij tot de conclusie gekomen, dat tijdelijke arbeidscontracten sommige mensen beter passen en voor anderen de weg naar een volledige baan kunnen betekenen. Wel blifft er de vraag, of het streven naar flexibilisering op de arbeidsmarkt niet kan ontaarden in een soort tweedeling op de arbeidsmarkt tussen een vaste kern en een groeiende groep van marginale werkers. In feite komen we dan op een soort driedeling: 1. 

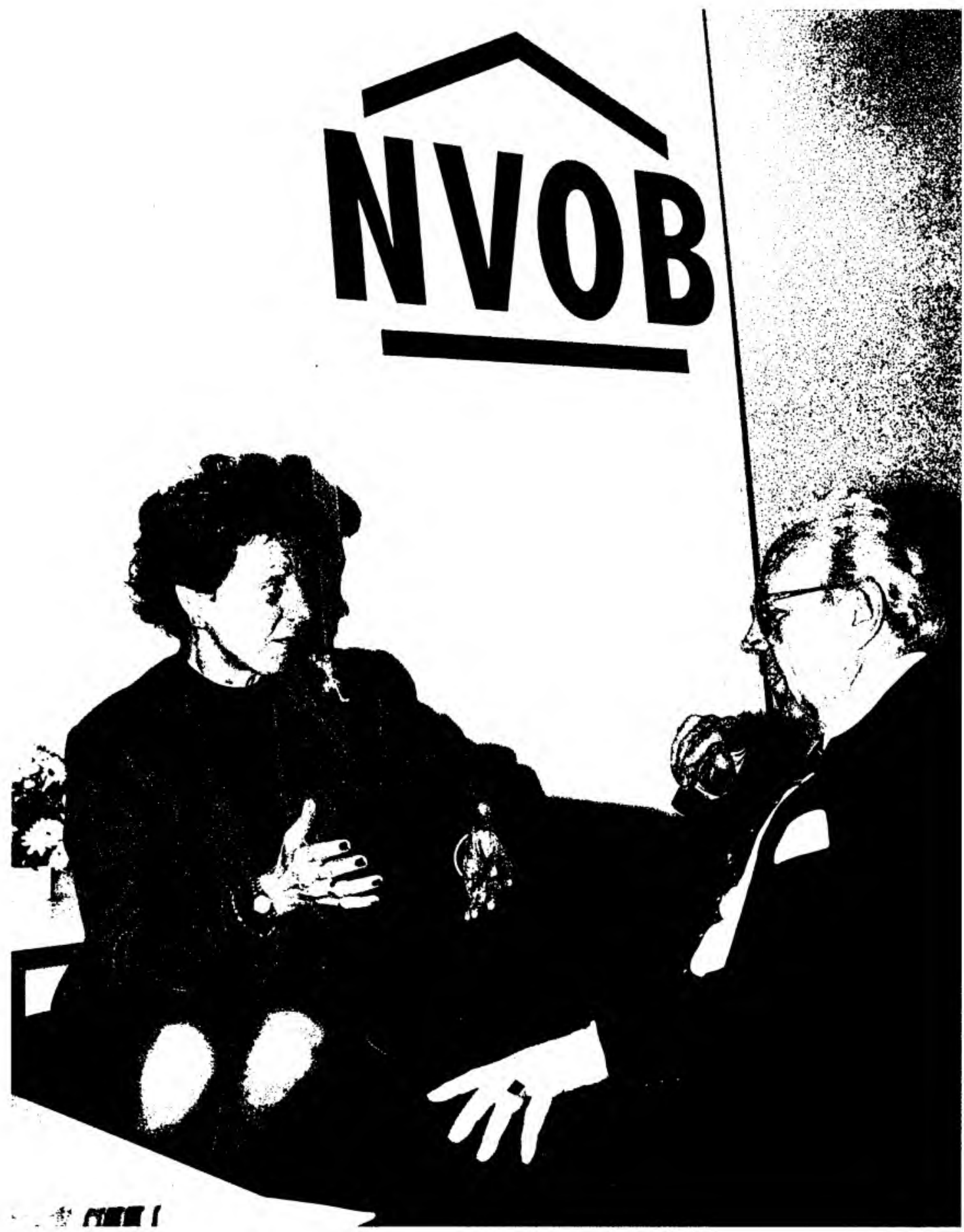

Neelie Kroes en Wil Albeda, Rotterdammers naast elkaar. 
vaste kern, 2. marginalen, 3 . mensen die er niet in slagen tot de arbeidsmarkt door te dringen. Hoewel er veel mensen zijn die vroegtijdig de stap van 3 naar 2 en dan naar 1 zullen kunnen nemen, is er een groeiende groep van mensen die in 3 of 2 bliff steken.

Interessante discussiepunten. Mar geen van alle zo wezenlijk, dat men zou kunnen spreken van een "einde van de overlegeconomie". Het gat veeleer om veranderingen in het functioneren ervan.

Overlegeconomie is een typisch Nederlandse term waarvoor geen internationaal equivalent bestat. In een recente studie van het International Labour Office te Geneve ${ }^{10}$ wordt kernachtig gesproken over "systems of national-level participation by representatives of workers and employees in government policy making". Het is, zegt Anne Trebilcock, in laatste instantie gebaseerd op een ideologie die pleit voor een "certain accomodation between distinct interests, implicity rejecting both the ideology of class struggle and unrestrained capitalism". In ruil voor een funclamentele arbeidsvrede en een redelijke opstelling van vakverenigingen en werkgevers, staat de regering een stuk van haar monopolie om beleid te voeren en bepaalde diensten te verlenen (m.b.t. arbeiclsverhoudingen en sociale zekerheid) af.

Zulke relaties veronderstellen een zekere mate van centralisatie in het stelsel van arbeidsverhoudingen. De ILO-studie laat echter zien, dat decentralisatie der onderhandelingen zulke centralisatie, war het betreft de relaties tussen regering en centrale organisaties, niet uitsluit. Er wordt regelmatig op gewezen, dat door de mondialisering van de economie en door de ontwikkeling van de ene Europese ruimte de betekenis van de nationale regering afneemt. Tot nu toe kan echter vastgesteld worden dat de arbeidsverhoudingen ook binnen de E.U. bijna uitsluitend nationaal blijven functioneren, terwijl mede daardoor het sociaal-economische beleid in sterke mate onder de competentie van de nationale regeringen blifft vallen. Interessant is het in dit verband te constateren, dat de Nederlandse regering de SER vroeg met het ong op de globalisering en Europeanisering de overlegeconomie te versterken. De SER ging hier in het bekende advies ${ }^{11}$ van 1992 positief op in.

${ }^{10}$ Anne Trebilcock e.a., Tripartice cooperation in national economic and social policy making, Geneve 1994.

$"$ SER, Advies convergentie en overlegeconomie 92/15 (1)en Haag, 1992) 
Ik vond in cle interessante nabeschouwing, die A. de Swaan schriff bij Maiaten van Bottenburgs bundel "Aan den Arbeid" bij het vijftig jaar bestaan van de Stichting van de Arbeid een citaat valn mijzelf waarin alangegeven wordt dat de overlegeconomie zich niet beperkt tot het officiële contact op centraal niveau. Minstens zo belangrijk zijn cle vele contacten zowel formeel als informeel tussen werkgeversorganisaties, valkverenigingen en departementen. Het sociaal economisch beleid word stap voor stap begeleid door overleg. Maar ook op vele andere terreinen kan men het bestaan van voortclurend overleg tussen departementen en matschappelijke organisaties vaststellen. Het overleg houdt in dat expertise, informatie en opinies worden uitgewisseld tussen bij het beleid betrokken organisaties en departementen. Alleen langs de weg van dit overleg kan afstemming tussen het beleid van overheid en maatschappelijke organisaties worden gerealiseerd in een pluralistisch bestel, zoals dat samenhangt met het bestaan van een markteconomie ${ }^{12}$ Daarbij is clan de getripartiseerde arbeidsvoorziening nog niet eens vermeld.

Zij, clie het primaat van de politiek als leidraad van hun handelen zien, vergeten dat naast het staltsrecht ook economische en sociologische referentiekaders de randvoorwaladen voor een evenwichtig functionerende simenleving vormen.

De overlegeconomie functioneert dus nog steeds, ondanks alle twijfel daarover. Mar hoe staat het met de toekomst daarvan?

De toekomst is onvoorspelbaar. Terugblikkend over de laatste 40, 45 jaar die ik actief mee makkte, komt die waarheid onverbiddelijk op je af. In clie jaren zagen wij de realisering van volledige werkgelegenheid en de ontwikkeling van de verzorgingsstaat, en in wezen vrijwel onmiddellijk daarop volgend de groei naar massawerkloosheid en de geleidelijke afbrokkeling van de verzorgingsstaat. We zagen Europa zich verenigen, zonder dat dit dat proces verlichtte. De mondialisering van cle economie, de ineenstorting van het Sovjet blok en de overgang van Oost Europa naar de markteconomie. En wie had dit alles 10, 20 jaar geleden, om maar te zwijgen over 30 of 40 jaar, kunnen voorzien?

Ik clenk dat zulke overwegingen ons in ieder geval enige bescheidenheid zouden kunnen bijbrengen. We gaan tastenderwijs voort. Toch

12 W. Albeda, De toekomst van de overlegecononie in: N.A. Hofstra en P.W.M. Nobelen, Toekomst van de overlegeconomie, Assen/Maastricht, van Gorcum 1993. 


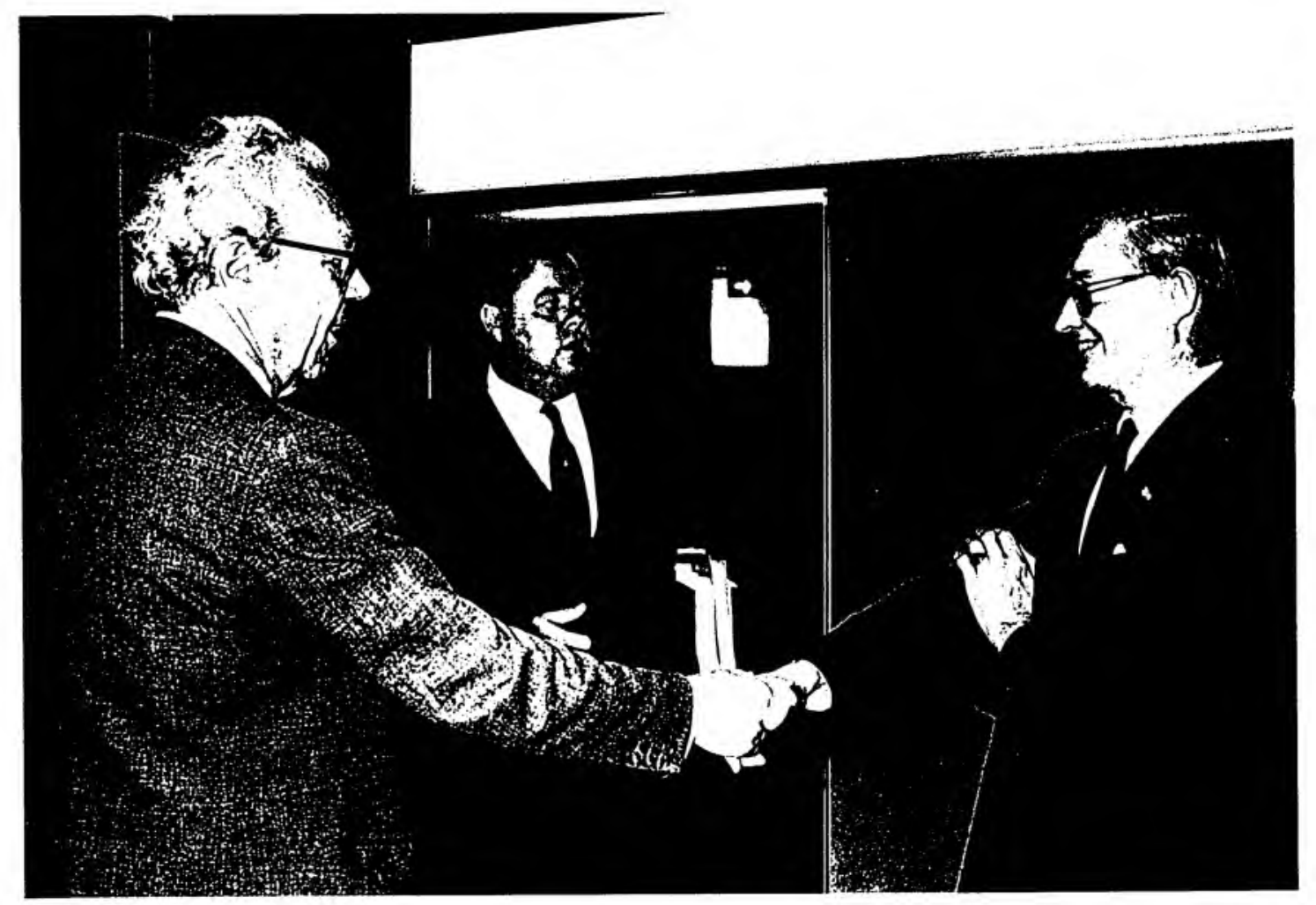

W. Albeda, Th. H. Dragt,

m: W. Scholten. Gescbilbeslechting Raad van State door de Adviesen Arbitragecommissie Rijksdienst.

zou ik niet aanraden om het hierbij te laten. We behoeven niet helemaal onwetend te zijn, ondat de toekomst, in de zin van waar te nemen tendenties, reeds aanwezig is. Ook al blijkt het vaststellen van clie tendenties vooral achteraf goed mogelijk te zijn, we kunnen nu in ieder geval zoeken naar en ons uitgangspunt nemen in die tendenties die al zichtbaar zijn. Bovendien mogen we er vanuit gaan, dat de wereld uiteindelijk gevormd wordt door de idecën der mensen, ideeën die bepalen op welke wijze de mensheid ongalat met de mogelijkheden en onmogelijkheden. Als we weten waar we heen willen, dan weten we nog niet waar we titeindelijk zullen uitkomen. Maar toch.

Vakverenigingen en werkgeversorganisaties hebben een brede, maar toch beperkte doelstelling (of functie). Het gaat om de contractuele en wettelijke regeling van de arbeid, om een rechtszekere, veilige en rechtvaardige positie voor diegenen die hun arbeid in een positie van afhankelijkheid verrichten. $\mathrm{Zij}$ dragen een systeem van arbeidsverhoudingen (samen met werkgevers en overheid), dat in ons type 


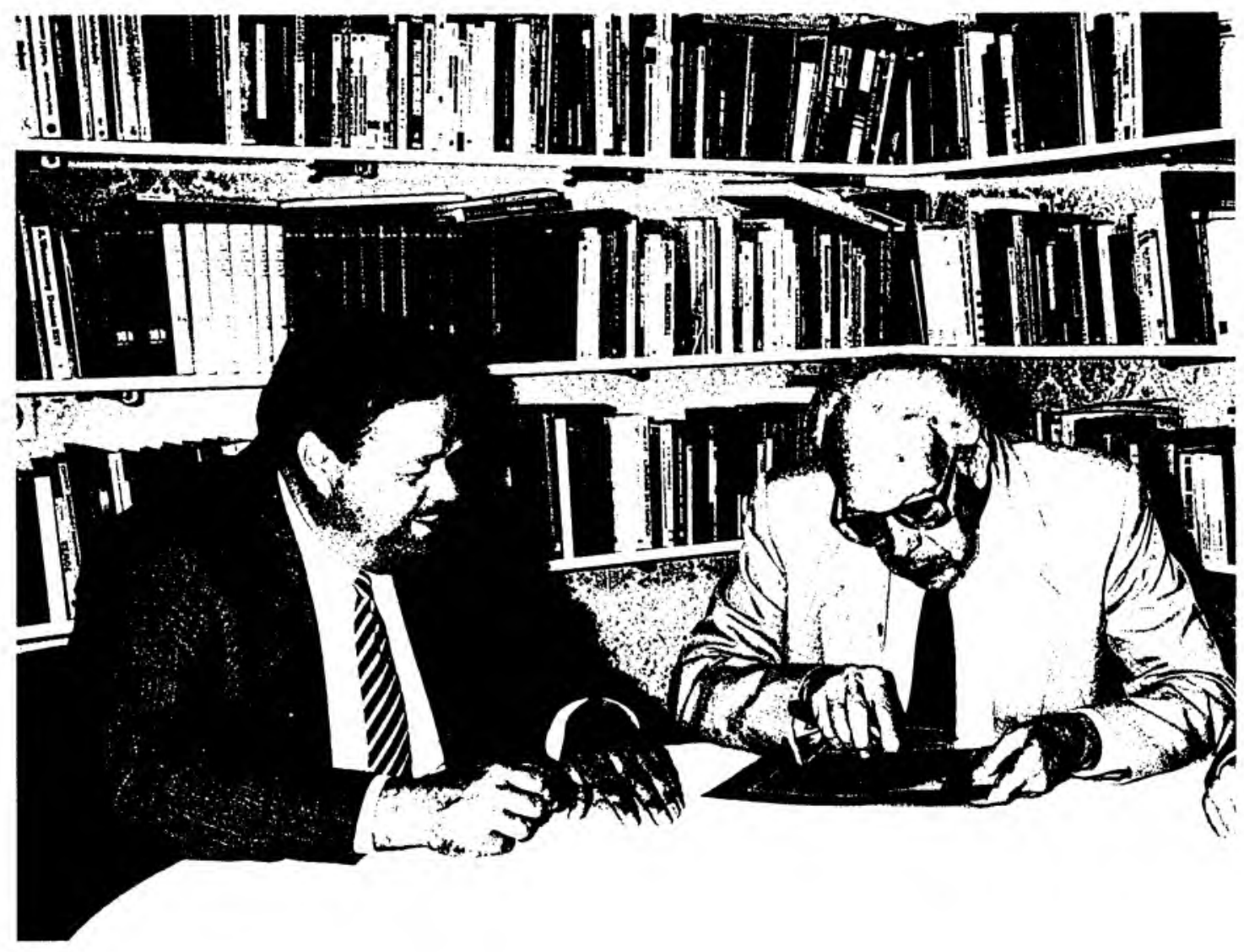

Eerste final offer arbitrage in de publieke sector; laatste bod onder gesloten comert.

samenleving een min of meer zelfstandig subsysteem vormt van de matschappij ${ }^{13}$.

Dit systeem kan in meerdere of mindere mate verstrengeld zijn met het politiek/bestuurlijke systeem van een land. Bij een sterke mate van verstrengeling spreekt men wel van neo-corporatisme (neo, om de indruk dat het gaat on corporatisme als een autoritair regiem te vermijden). In Nederland functioneren organen als SER, Stichting van cle Arbeid en de uitvoeringsorganen van de sociale zekerheid als peilers voor zo'n (sinds de jaren zeventig niet al te effectief) neo-corporatief regiem.

In een neo-corporatief regiem alanvaarden de sociale partners (mede) verantwoordelijkheid voor het sociaal-economisch beleid. Dit kan

${ }^{13}$ J.T. Dunlop, Industrial relations system, New York 1958. 
betekenen, dat de loonvorming ingepast wordt in de mogelijkheden van de nationale economie. Een neo-corporatief bestel past in het model van een "georganiseerd kapitalisme". Dit model is de laatste jaren steeds duidelijker onder druk komen te staan. Men kan daarvoor zowel op ideologische als meer feitelijke omstandigheden wijzen. In de eerste platats is er een onmiskenbare zegetocht van neo-liberaal denken te constiteren. In de tweede plaats is er de ontwikkeling naar een mondiale economie, een economie zonder grenzen. Deze twee trends, de ideologische en de feitelijke ontwikkeling, vertonen - uiteraard samenhang.

De monclialisering heeft te maken met de verbeterde communicatie, het goedkoper transport, het verdwijnen van het Sovjetsysteem, en het naar voren komen van nieuw geindustrialiseerde landen, m.n. in Z.O. Aziè. De mondialisering leidt in eerste instantie tot een versterkte concurrentie, met name waar het betreft produkten die met betrekkelijk eenvoudige arbeid worden voortgebracht. Alle industrieën, die daardoor gekwalificeerd zijn, staan onder druk. Ook wat meer geschookde arbeid wordt geconfronteerd met de invloed van de (zich ontwikkelende) wereldarbeidsmarkt. Maar reeds kondigt zich een verder stadium aan, warin ook hoger gekwalificeerde arbeid, tegen voorlopig nog lagere lonen, op de wereldarbeidsmarkt wordt aangeboden. De concurrentie op de loonmarkten heeft uiteraard met alle loonkostenverhogende elementen van doen. Het is zeer de vraag in hoeverre een (via loonheffingen gefinancierde) verzorgingsstaat in cle mondiale economie kan overleven. De mondiale concurrentie leidt er toe dat veel industriële ondernemingen mar ook ondernemingen in de dienstensectoren, opereren op een wereldmarkt die maar ten dele door de nationale (of door cle supranationale E.U. overheid) te reguleren is. Hier ligt het aangrijpingspunt voor het nieuwe liberalisme.

Het neo-liberale clenken past kennelijk in de tijdgeest. Reeds vier jaar geleden constateerde Albert Michel verbaasd, dat georganiseerd kapitalisme zeker niet minder effectief en concurrerend behoeft te zijn dan vrij kapitalisme maar toch in de icleologische strijd terrein verliest, zelfs in landen die voorbeelden vormen van een georganiseerde economie.

Het was te verwachten dat de neo-liberale ideologie juist zou toeslaan daar waar het de economie van de arbeidsmarkt betreft. De vakbeweging wordt door deze ideologische ontwikkeling aangesproken op 
halar manier van functioneren in de moderne samenleving. Daarbij kont, dat de trend naar liberalisering en individualisering ook de organisatiegraad valn de werknemers niet bevordert. De organisatiegraad bereikte in de jaren zeventig in Nederland een top. Van de achteruitgang der ledentallen zijn wij, m.n. in de private sector, nog niet bekomen. Dit heeft gevolgen voor de relatieve machtspositie van de vakverenigingen, en voor de noodzaak werfkracht te behouden.

De Economist ${ }^{1.4}$ wijst op de volgende factoren, die verantwoordelijk zijn voor de lagere organisatiegraad:

- Er is een relatie tussen de omvang van de onderneming en de organisatiegraad. Het is gemakkelijker en goedkoper mensen te organiseren in een onderneming met 1000 man personeel dan in 10 ondernemingen met 100 man. De gemiddelde omvang van ondernemingen claalt.

- In de dienstensector, maar vooral in de nieuwste dienstensectoren is de organisatiegraad lager. Maar in die sectoren vindt de werkgelegenheidsgroei plaats.

- Juist in sterk gecentraliseerde stelsels van arbeidsverhoudingen zijn vakverenigingen sterk. Maar de centralisatie neemt af.

- Mensen willen niet langer de steun van de traditionele hulporganisalties, van kerken tot valkverenigingen.

- Men kan er voorts op wijzen, dat HBO-ers minder georganiseerd zijn dan geschookde arbeiders. Maar zij vormen een groeisector.

Is cle lage organisatiegraad een onvermijclelijk nevenverschijnsel van de moderne ontwikkeling, zodat de hoop op een blijvend goed georganiseerde arbeidsmarkt moet worden opgegeven? Men kan hierover drie opmerkingen maken. In de eerste plaats geldt, dat het beeld van de situatie in verschillende landen niet eenduidig is. Nalast landen met een dalende organisatiegrad zijn er de landen met een traditionee] sterke vakbeweging, waar de vakbeweging zijn sterke positie behoudt en ook weet te veroveren in de nieuwe bedrijfstakken.

In de tweede plaats kan men er op wijzen, dat de goed georganiseerde verzorgingsstaat voor veel potentiële vakbondsleden een excuus vormdle voor "free-riders' gedrag". Met de systematische terugtred van

1+ Econonist, 1 juli 1995. 


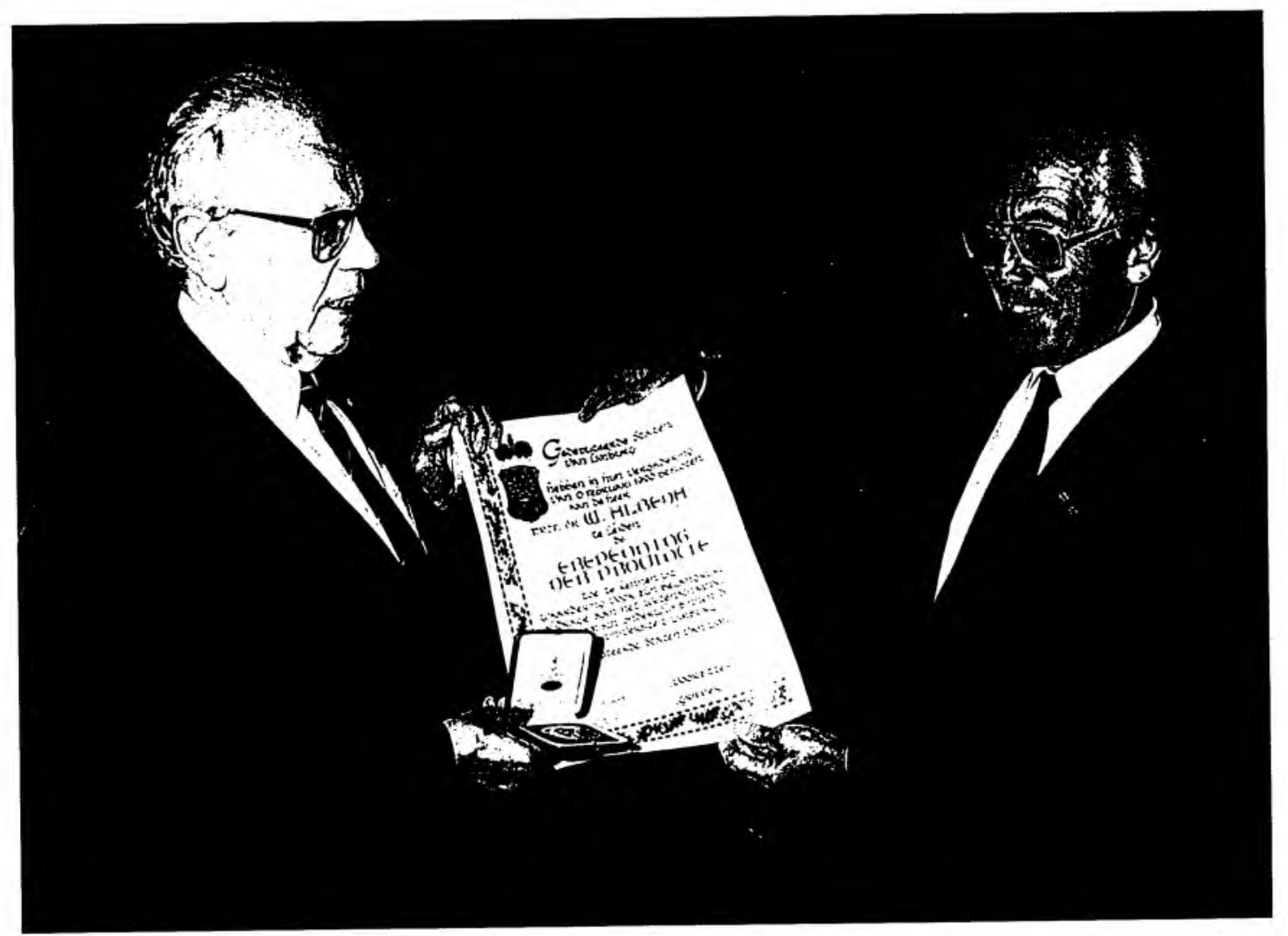

Uitreiking ere-medaille door gouverneur E. M. Mastenbroek van Limburg.

de overheid wordt dit excuus steeds zwakker. Het is denkbaar dat hier een nieuwe impuls ligt om zich te organiseren ${ }^{15}$.

In de clerde plaats zou de vakbeweging hier, wat betreft haar beleid, een voorbeeld kunnen nemen aan de landen met een hoge organisatiegraad. Presentie in de onderneming, service voor leden, goede afhandeling van klachten, zijn evenzovele punten waaraan nog veel te doen is.

Maar daarbij kan natuurlijk de vraag gesteld worden of er niet een groeiende groep werknemers is, die inderdaad geen behoefte hebben aan de steun van een vakvereniging. In imperfekte markten met grote machtsongelijkheid is de argumentatie voor organisatie der marktpartijen sterk. Naar mate de markt voldoet aan de eisen, die economisten

${ }^{15}$ Klanderman en Visser, (redactie) De vakbeweging na de werkvaansstaat, Van Gorcum, Assen 1995. 


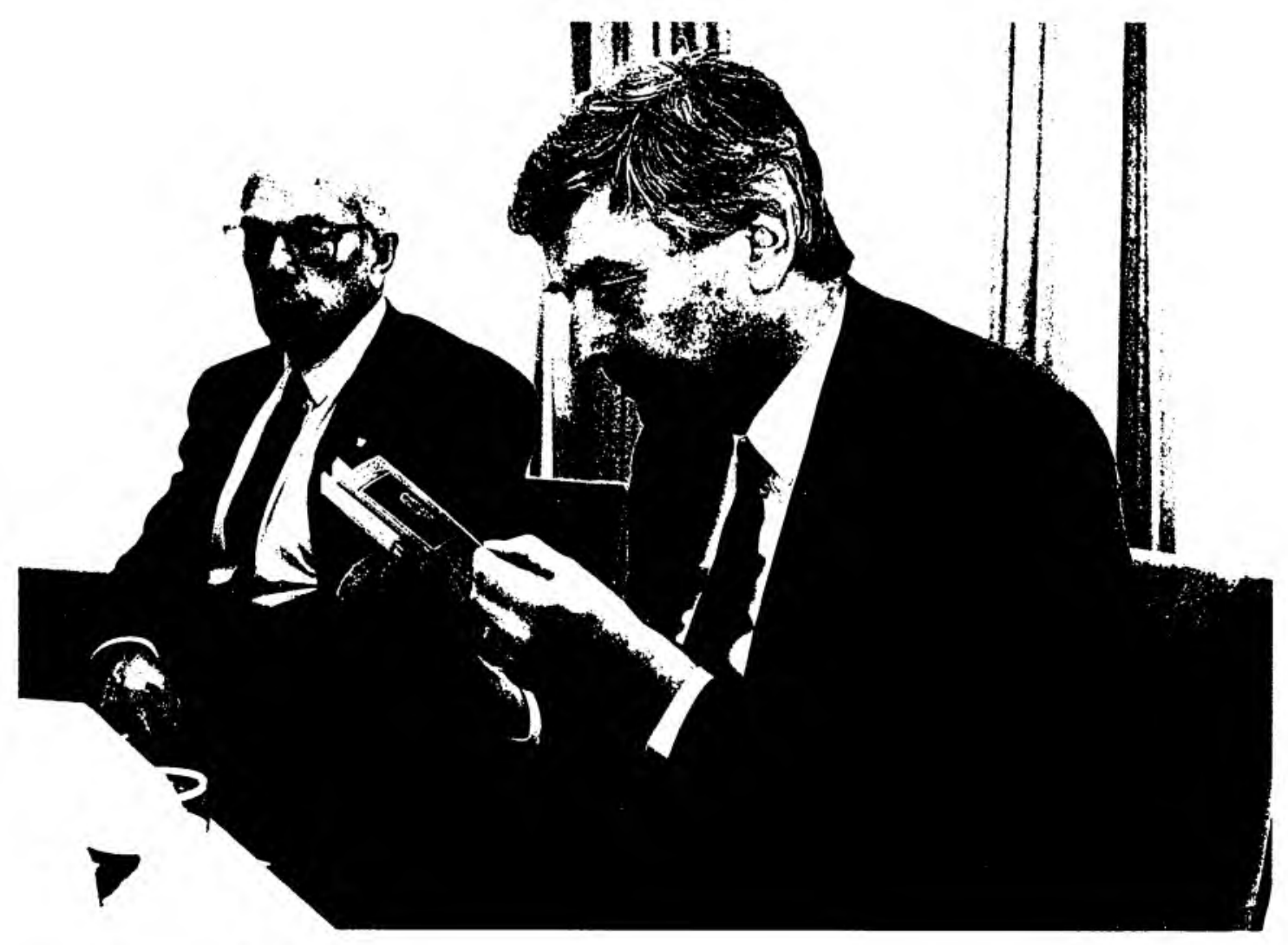

Lubbers ontmoet Albeda en

Thomas More 1992.

daaraan stellen, en met name walar de machtsongelijkheid verdwijnt (m.n. doordat werknemers over schaarse eigenschappen en valardigheden beschikken, en een goed marktoverzicht hebben op een relatief kleine markt), is de behoefte aan organisatie gering. Zulke werknemers zijn er altijd geweest, maar waarschijntijk neemt hun alintal, dankzij de nieuwe technologie en de hogere opleiding, die claarmee samenhangt, toe. Maar er blifft een grote groep van werknemers voor wie dit niet geldt.

Theoretisch kan men ons voorrekenen, dat perfecte markten altijd beter werken clan organisaties en georganiseercle markten. Rietdijk wordt niet moe daar op te wijzen ${ }^{16}$ en hij zet vakverenigingen permanent in de beklaagdenbank. Hij heeft het tij mee. Toch overdrijft hij . Er zijn geen perfecte markten en zeker cle arbeidsmarkt is imperfect.

16 The Scientifization of Culture, Van Gorcum, Assen 1994. 
Maar meer dan ooit realiseren wij ons thans dat "de gewone mensen" via het al of niet kiezen voor organisatie, uitmaken of een georganiseerde arbeidsmarkt haalbaar is. Alternatieven daarvoor, zoals de gezamenlijke werkgevers of de overheid, lijken niet aantrekkelijk. Het zou wel eens zo kunnen zijn dat regeringen die hopen op een georganiseerde arbeidsmarkt, een redelijke organisatiegraad als doelvariabele zullen moeten accepteren.

Ik noem een paar andere hinderpalen voor een blijvend georganiseerde arbeidsmarkt:

1.

De positie van de vakbeweging wordt thans in sterke mate aangetast door de blijvend hoge werkloosheid. In het nieuwe liberale klimaat is Keynes afgezworen en men ziet slechts in de vrije markt (ook de arbeidsmarkt) de weg naar volledige werkgelegenheid (al durven we die terminologie niet meer te gebruiken). Ik geloof niet, dat dit uiteindelijk de weg zal zijn naar herstel van de werkgelegenheid. Het zou wel eens zo kunnen zijn, dat alléén een fundamentele ombouw van de verzorgingsstaat herstel van de werkgelegenheid kan brengen. Financiering van uitkeringen zal grotendeels moeten wijken voor de financiering van banen in die (nuttige) sectoren, die functies vervullen die alleen door mensen, maar niet door robots vervuld kunnen worden!

De vrije markt alleen brengt ons de volledige werkgelegenheid niet. Maar de blijvend tekortschietende werkgelegenheid ondermijnt wel de georganiseerde arbeidsmarkt.

2.

Het verlangen van werkgevers en regeringen naar meer flexibele arbeidsverhoudingen, botst met het streven der vakverenigingen naar zekerheid en rechtszekerheid voor hun leden. Meer en meer gaan zij echter inzien, dat alleen maar oppositie tegen deze verlangens niet werkt. Bovendien, tegenover het verlangen van werkgevers naar maatwerk en flexibiliteit staan niet alleen maar op stanclaardisatie van werktijden en werkmethoden beluste werknemers. Door de toenemende participatie van vrouwen en groeiende diversiteit der leefvormen, zijn er ook veel werknemers die vragen om andere dan gestandaardiseerde arbeidstijden en werkvormen. Dit betekent, dat er ruimte is voor nieuwe compromissen met werkgevers. Het compromis waarbij 


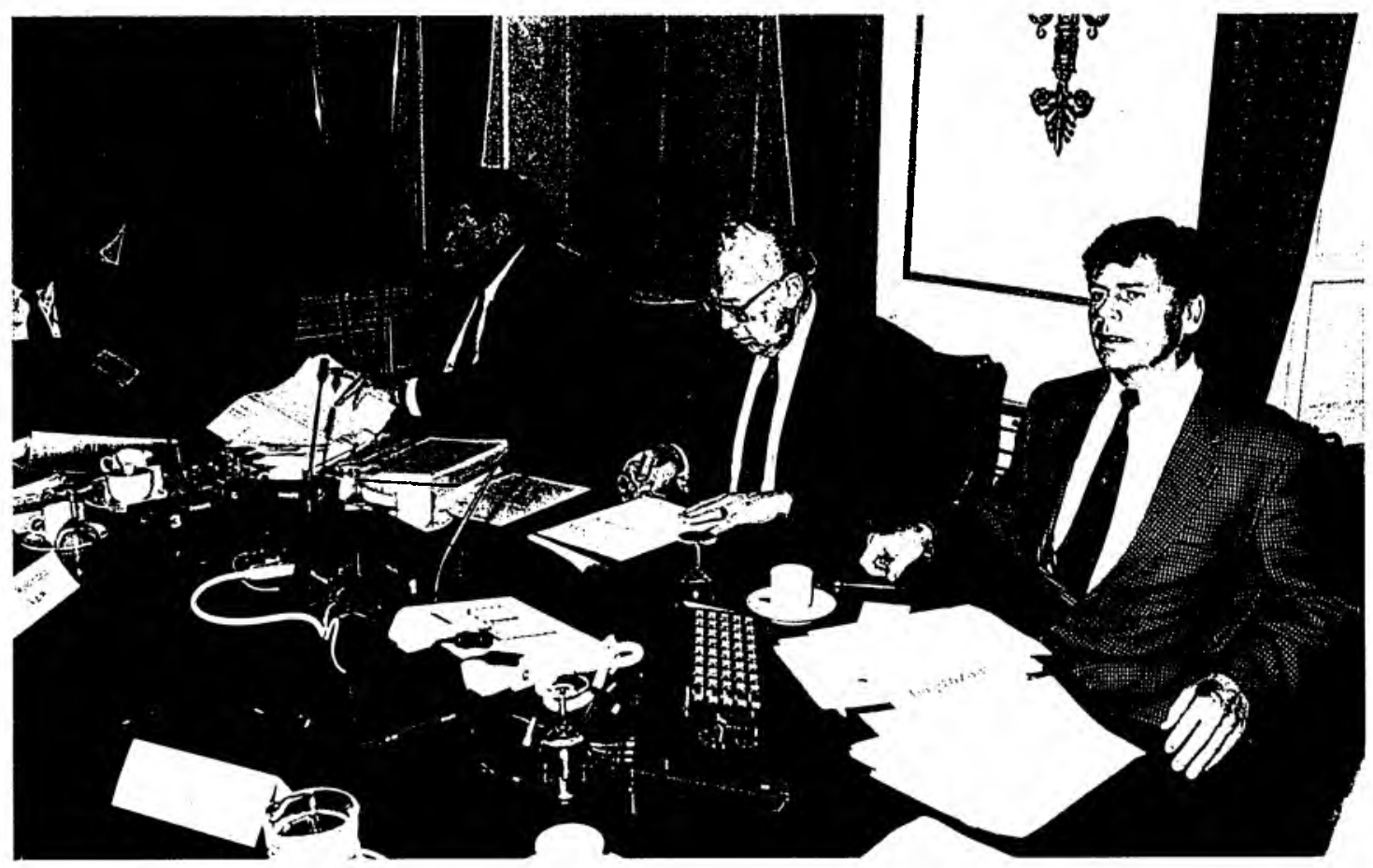

Bimnenschippers conflict 1993 met ondersteuning van Tb. H. Dragt en N. van Dam.

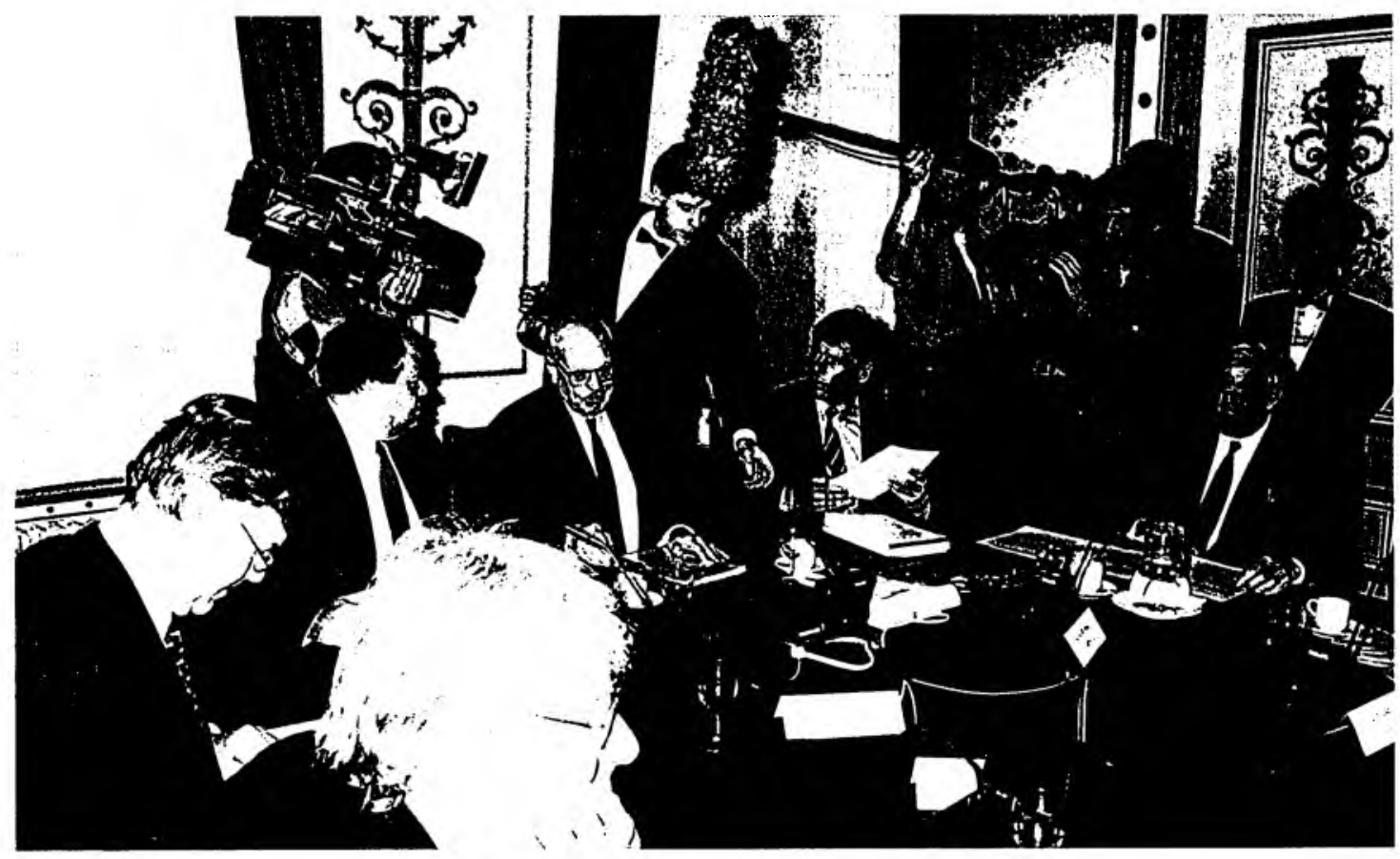


arbeidstijdverkorting en flexibilisering tegenover elkaar worden uitgeruild is een voorbeeld.

Flexibilisering kan ook in een georganiseerde arbeidsmarkt tot ontwikkeling komen.

3.

Albert stelt dat we sinds 1991 terecht gekomen zijn in de fase, waarbij het kapitalisme gepresenteerd wordt niet, zoals in de sociale markteconomie, als een markteconomie in symbiose met een sociaal actieve staat, maar in de meeste gevallen als een alternatief voor de staat. Deze tendentie kan versterkt worden door, wat de WRR noemde, de "onvoltooide integratie" van West Europa. Op nogal wat beleidsterreinen verliest het nationale beleid van overheid en maatschappelijke organisaties z'n effectiviteit door het ontstaan van de ene economische ruimte. Maar het supranationale beleid op het Europees nivo, dat in plats van het nationale beleid zou moeten ontstaan, is er (nog?) niet. Europese vakverenigingen, die binnen de Europese ruimte opereren en daar arbeidsverhoudingen ontwikkelen, bestalan nog niet of bestaan nauwelijks. Men ziet beleidsconcurrentie ontstaan. Wanneer bedrijven concurreren, dan kan men daarachter de concurrentie zien van de stelsels van arbeidsverhoudingen en van sociale zekerheid. Bij ontstentenis van Europees Sociaal Beleid zou dit er toe kunnen leiden, dat ieder land in concurrentie met alle andere lidstaten gaat werken in de richting van sociale deregulering. Terecht kan Albert er op wijzen dat de EU zo het Rijnlandse model zou kunnen ondermijnen. Daarin ligt her belang van het Europese Sociale Protocol van Maastricht.

Reeds eerder wees bijvoorbeeld Alain Cotta ${ }^{17}$ op de onverenigbaarheid van nationale soliclariteit en internationale concurrentie. Hier ligt een conflict, warmee de Internationale Arbeidsorganisatie zich reeds sinds 1919 heeft bezig gehouden. In de conventies van deze organisatie liggen cle eerste contouren van een internationaal sociaal beleid en internationale arbeidsverhoudingen. Thans wordt ook de nieuwe werekthandelsorganisatie met deze problematiek geconfronteerd.

Matar reeds op het Europese niveau geeft de concurrentie tussen liclstaten problemen. Europese arbeidsverhoudingen, met Europese collectieve arbeidsovereenkomsten en Europese medezeggenschapsvormen, ontwikkelen zich nog niet. Ook een Europese Verzorgingsstaat

1) Alain Cotta, Le Triomphe des corporations, Grasset, Parijs 1983. 
De beer en meurouw Albeda lemidden van bun micro-kosmos, 1994.

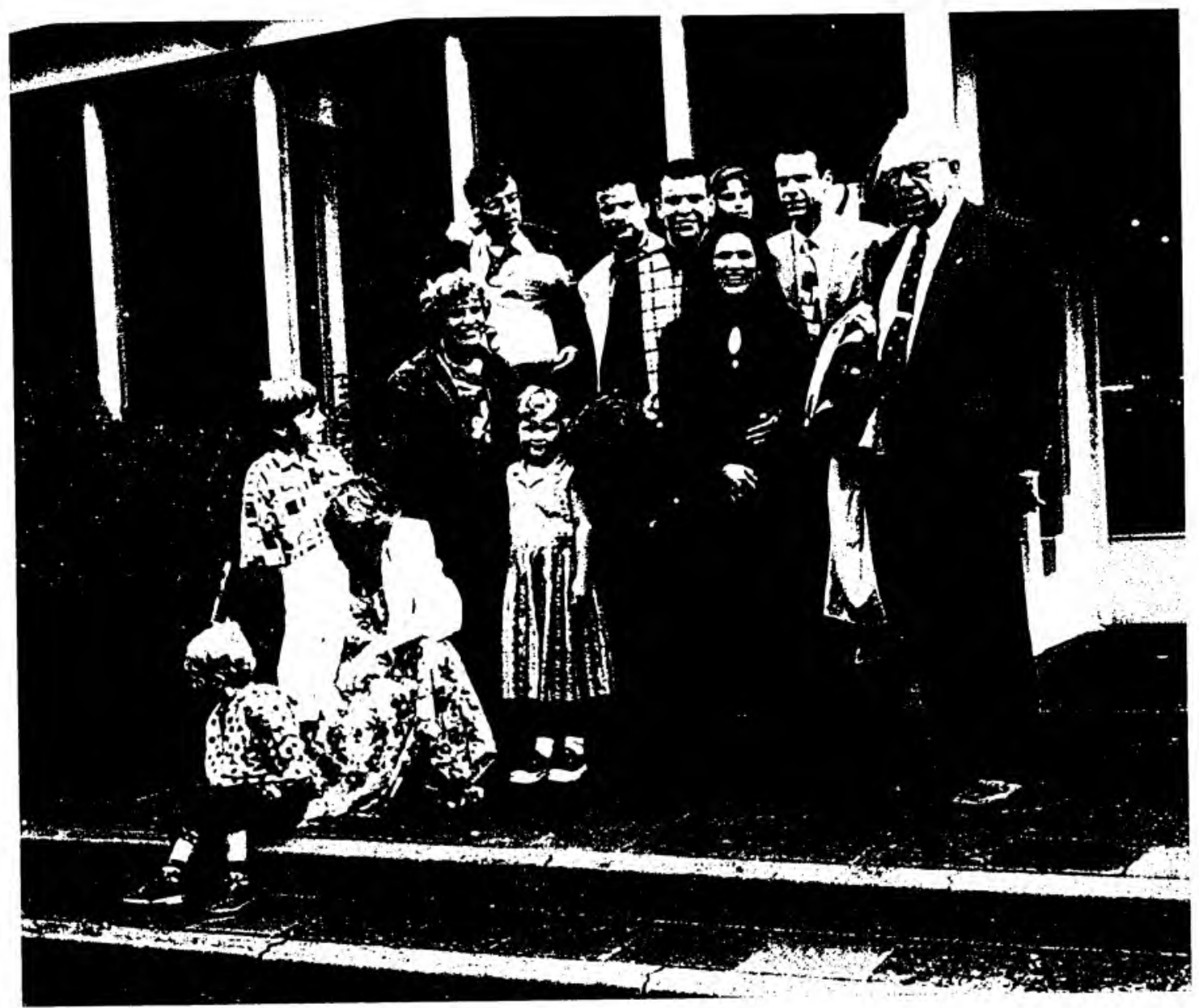


dat er internationatal georganiseerde alternatieven ontstaan. Ik kom terug op het begin van mijn betoog. Wij konden ons aan het begin van deze eeuw geen nieuwe maatschappijvorm denken zonder daarbij atandacht te schenken aan de betekenis der matatschappelijke organisatties De staat was - in cle woorden van Schmitter - "al necessary but not a sufficient actor in social concertation ${ }^{1 \text { ".". }}$. Moeten we vaststellen, dat het thans door verzwakking van de vakvereniging, door mondiatlisering en Europeanisering anders ligt? Hebben wij thans nog slechts te kiezen tussen de nationale overheid (met hatr afgenomen mogelijkheden) en de ongeorganiseerde arbeidsmarkt? En daarmee zijn wij terug bij Gerbrandy 's strijd, een strijd die de moeite waard blijft omdat beide alternatieven onalanvaardbaar zijn en onalanvalardbatar blijven.

Het lijkt mij clat het te vroeg is om, wanneer het om het functioneren, organiseren en bewerktuigen van de arbeidsmarkt gaat, te stellen dat de nationale overheid en nationale matatschappelijke organisaties uitgeteld zijn. Marktorganisatie blijft zowel nationaal als Europees in vele gevallen een menselijk en vaak ook meer efficiënt alternatief voor de ongeorganiseerde markt. Terwijl de supranationale structuren aarzelend worden opgebouwd moeten de nationale tijlens de verbouwing doorgaan.

De strijd blijft, op elk niveau.

${ }^{18}$ Anne Trebilcock, A.W. 